\title{
1 Abrupt transitions in the NAO control of explosive North
}

3

\section{Atlantic cyclone development}

Iñigo Gómara ${ }^{1,2^{*}}$, Belén Rodríguez-Fonseca ${ }^{1,2}$, Pablo Zurita-Gotor $^{1,2}$, Sven Ulbrich $^{3}$, and Joaquim G. Pinto ${ }^{3,4}$ (1)
Running Title: Non-stationary variability of North Atlantic bombs

${ }^{1}$ Dpto. Geofísica y Meteorología, Universidad Complutense de Madrid, Madrid, Spain

${ }^{2}$ Instituto de Geociencias (IGEO), UCM, CSIC, Madrid, Spain

\author{
${ }^{3}$ Institute for Geophysics and Meteorology, University of Cologne, Cologne, Germany
}

\author{
${ }^{4}$ Department of Meteorology, University of Reading, Reading, United Kingdom
}

\footnotetext{
*Correspondence to: Iñigo Gómara, Dpto. Geofísica y Meteorología, Universidad Complutense de Madrid, Facultad de CC. Físicas, Ciudad Universitaria s/n. 28040 Madrid, Spain. E-mail: 1.gomara@ucm.es
} 


\section{Abstract}

25 Explosive cyclones are intense extra-tropical low pressure systems featuring large deepening rates. In the Euro26 Atlantic sector, they are a major source of life-threatening weather impacts due to their associated strong wind 27 gusts, heavy precipitation and storm surges. The wintertime variability of the North Atlantic cyclonic activity is 28 primarily modulated by the North Atlantic Oscillation (NAO). In this study, we investigate the interannual and multi-decadal variability of explosive North Atlantic cyclones using track density data from two reanalysis datasets (NCEP and ERA-40) and a control simulation of an atmosphere/ocean coupled General Circulation Model (GCM - ECHAM5/MPIOM1). The leading interannual and multi-decadal modes of variability of explosive cyclone track density are characterized by a strengthening/weakening pattern between Newfoundland and Iceland, which is mainly modulated by the NAO at both timescales. However, the NAO control of interannual cyclone variability is not stationary in time and abruptly fluctuates during periods of 20-25 years long both in NCEP and ECHAM5/MPIOM1. These transitions are accompanied by structural changes in the leading mode of explosive cyclone variability, and by decreased/enhanced baroclinicity over the sub-polar/subtropical North Atlantic. The influence of the ocean is apparently important for both the occurrence and persistence of such anomalous periods. In the GCM, the Atlantic Meridional Overturning Circulation (AMOC) appears to influence the large-scale baroclinicity and explosive cyclone development over the North Atlantic. These results permit a better understanding of explosive cyclogenesis variability at different climatic timescales and might help to improve predictions of these hazardous events.

43 Keywords: extra-tropical cyclones; explosive cyclogenesis; NAO; jet stream; ocean variability; AMOC. 


\section{Introduction}

The wintertime variability in the mid-latitudes of both hemispheres is dominated by the occurrence of subweekly baroclinic disturbances (Blackmon et al. 1977; Lau 1978). Such disturbances typically grow in the vicinity of the planetary stationary troughs, where the gradients of temperature and humidity are maximum (Hoskins and Valdes 1990), and terminate near the regions of stationary ridges (Lau 1988). In the northern hemisphere, these areas (so called 'storm tracks') extend from the Eastern Asian and North American coast lines towards Western North America and Europe, respectively (Hoskins and Valdes 1990). In both oceanic basins, the storm track maximum lies northeast of the upper-level polar jet stream core, which is semi-permanently located over Japan and eastern North America, respectively (Chang and Orlanski 1993; Woollings et al. 2010). Such a configuration is consistent with surface baroclinic disturbances crossing the jet core from the rightentrance toward the left-exit regions, where strong upward motion of air fosters further cyclone amplification (Uccellini 1990; Rivière and Joly 2006). Additionally, upper-level mobile troughs (Bosart and Lin 1984; Sanders 1986; Reader and Moore 1995; Gyakum and Danielson 2000), and surface sensible and latent heat fluxes (Fosdick and Smith 1991; Davis and Emanuel 1988) also contribute to extra-tropical cyclone intensification. The characteristics of these dynamical precursors and their relative vertical position (Hoskins et al. 1985) typically determine the deepening rate (Pettersen and Smebye 1971; Fink et al. 2012) and life cycle of cyclones (Bjerknes and Solberg 1922; Shapiro and Keyser 1990). In the literature, surface cyclones featuring strong intensification rates (equal or above $24 \mathrm{hPa} \mathrm{day}^{-1}$ at $60^{\circ} \mathrm{N}$, or equivalent) are denominated 'explosive cyclones' or 'bombs' (Sanders and Gyakum 1980). These explosive cyclones are associated with strong impacts like wind gusts, heavy precipitation and storm surge events (Bosart and Lin 1984; Wernli et al. 2002).

Over the North Atlantic, the most prominent pattern of climate variability is the North Atlantic Oscillation (hereafter NAO; cf. Wanner et al. 2001). It represents a redistribution of air masses between sub-tropical and sub-polar latitudes, and modulates the strength and latitudinal location of the westerly flow (Marshall et al. 2001). Under its positive phase, the polar jet stream is accelerated and shifted to the northeast compared with its 'average' position. Under the negative phase, the jet stream is decelerated, constrained upstream in the North Atlantic and shifted to the south. The changed mean flow induces a latitudinal displacement of storm trajectories (Hurrell et al. 2003; Trigo 2006; Santos et al. 2013), and modulates their intensification rates (Gómara et al. 2014b). In this regard, the positive NAO phase is associated with stronger and more extensive baroclinicity over the North Atlantic than the negative phase. As a result, the number of intense cyclones over the North Atlantic increases (decreases) under NAO+ (NAO-) (Pinto et al. 2009). 
The synoptic temporal evolution of the NAO seems to be dominated by stochastic processes (Feldstein 2003), such as Rossby Wave-Breaking (RWB; Benedict et al. 2004; Woollings et al. 2008; Strong and Magnusdottir 2008). RWB appears to control explosive cyclogenesis (Hanley and Caballero 2012; Gómara et al. 2014a; Messori and Caballero 2015) and cyclone families over Western Europe (Pinto et al. 2014) at synoptic timescales, by constraining and accelerating the jet. It has been debated in the literature whether the lowerfrequency NAO variability (e.g., interannual, multi-decadal; James and James 1989; Wunsch 1999; Schneider et al. 2003; Raible et al. 2005) arises from pure climate noise (Stephenson et al. 2000), or is forced by external factors such as: (i) the interannual and lower frequency ocean variability in the North Atlantic (Raible et al. 2001; Visbeck et al. 2003; Rodríguez-Fonseca et al. 2006; Chen et al. 2015; Sun et al. 2015), tropical Pacific (Trenberth et al. 1998; Müller et al. 2008; Zhang et al. 2015) and the Indian ocean (Hoerling et al. 2001; 2004); (ii) the stratosphere (Baldwin and Dunkerton 2001; Reichler et al. 2012); (iii) solar variability (Shindell et al. 2001); and (iv) the mid-latitude westerly flow from the North Pacific (Honda et al. 2001; Pinto et al. 2011; Drouard et al. 2015), among others. Additionally, the role of anthropogenic climate change is another factor to consider. For example, there is some evidence of an intensification and eastward shift of the NAO dipole over the last decades of the $20^{\text {th }}$ century (Hurrell et al. 2003; Jung et al. 2003). However, it is still unclear whether such evolution is primarily due to global warming (Ulbrich and Christoph 1999; Osborn et al. 1999; Bader et al. 2011), internal decadal variability of the NAO (Wang et al. 2012; Raible et al. 2014; Woollings et al. 2015) or to the storm track itself (Rogers 1997; Lu and Greatbach 2002).

Previous studies have characterized multi-decadal changes in the dominant teleconnection patterns, such as NAO, and their associated impacts, e.g., on European precipitation (Raible et al. 2004; Vicente-Serrano and López-Moreno 2008), on the North Atlantic storm track (Luksch et al. 2005, Pinto et al. 2011), etc. Such lowfrequency changes often lead to active/inactive teleconnections between remote regions (e.g., between ENSO and European precipitation; López-Parages and Rodríguez-Fonseca 2012), thus providing enhanced forecast skill of relevant phenomena during specific periods of time (cf. Rodríguez-Fonseca et al. 2009; Losada et al. 2012).

This work primarily investigates the interannual variability of explosive cyclogenesis in the North Atlantic and its main potential drivers. Our focus is on the impact of the dominant modes of large-scale atmospheric variability (fundamentally NAO) and on the possible existence of different regimes of behavior as these modes and their associated teleconnections evolve in multi-decadal timescales. In addition, the multi-decadal variability of explosive cyclone tracks is also assessed. To address these questions, we use cyclone track density 
fields obtained from reanalyses and a long coupled model simulation with an objective cyclone tracking algorithm.

The article is organized as follows. Sections 2 and 3 present the data and methods used in this study. Section 4 describes the explosive cyclone variability and its large-scale driving in the reanalysis data sets, and section 5 extends this analysis using a long control simulation from a coupled model. The article concludes with a short summary of the main results.

\section{Data}

Both reanalysis and GCM data are considered for this study. The first reanalysis dataset is provided by the National Centers for Environmental Prediction (NCEP; Kalnay et al. 1996). The data used has a 6-hr resolution and extends from January 1948 to February 2012. The spectral spatial resolution is T62 (approximately $\left.2.5^{\circ} \times 2.5^{\circ}\right)$ and extends from the surface up to $3 \mathrm{hPa}$ (28 vertical levels). Additionally, data from the European Centre for Medium-Range Weather Forecasts (ECMWF) ERA-40 (Uppala et al. 2005) is considered. The data starts in September 1957, ends in March 2002, and is available 6-hourly with a spectral spatial resolution of $\mathrm{T} 159\left(\sim 1.125^{\circ} \times 1.125^{\circ}\right)$. The 60 vertical levels reach $0.1 \mathrm{hPa}$.

The sea surface temperature (SST) and sea ice data from the Met Office Hadley Centre (HadISST) are used. This monthly global dataset starts in 1870 and has a $1^{\circ} \times 1^{\circ}$ resolution (Rayner et al. 2003). The ocean heat content is estimated from the integrated temperature from 0 to $300 \mathrm{~m}$ from the Simple Ocean Data Assimilation (SODA) reanalysis (Carton and Giese 2008). The monthly fields have a horizontal resolution of $0.5^{\circ} \times 0.5^{\circ}$ and span 1950-2009.

We consider a coupled 505-yr control simulation with pre-industrial external forcing conditions (from year 1860) performed with the ECHAM5/MPIOM1 GCM (hereafter ECHAM5; Roeckner et al. 2003; Jungclaus et al. 2006). The atmospheric (oceanic) model has a spatial resolution of T63 (T31), with 31 (40) vertical levels from the surface up (down) to $10 \mathrm{hPa}(5720 \mathrm{~m})$. Oceanic and atmospheric models are coupled without further flux adjustments. The tropical SST variability is found realistic (Jungclaus et al. 2006). The storm track and NAO variability have also been evaluated in previous studies (e.g., Bengtsson et al. 2006; Pinto et al. 2011).

\section{Methods}

\section{Climate indices}



When not mentioned explicitly, a 31-point Lanczos filter with 11-yr. cut-off frequency is applied to the ECHAM5 data to separate interannual and multi-decadal timescales of variability. Filtering is not applied to reanalysis data due to the constraints posed by the short time series. Still, most of the spectral power density is concentrated within the band of 1 to $11-\mathrm{yr}$ (cf. Section 4). The following indices are considered:

- The NAO index (Figs. S1a-c), defined as the leading EOF of 500-hPa geopotential height (z500) winter seasonal anomalies over the area $\left(20-80^{\circ} \mathrm{N}, 80^{\circ} \mathrm{W}-40^{\circ} \mathrm{E}\right.$; Barnston and Livezey 1987).

- The Arctic Oscillation (AO, Figs. S1d-f) and Pacific North American Pattern (PNA, Figs. S1g-i), defined as the two leading EOFs of z500 winter hemispheric anomalies north of $20^{\circ} \mathrm{N}$ (NOAA CPC definition).

- The Niño-34 index (Figs. S2a-c), based on winter averaged high-pass filtered (1-13 yr.) SST anomalies over the area $\left(5^{\circ} \mathrm{S}-5^{\circ} \mathrm{N}, 170^{\circ}-120^{\circ} \mathrm{W}\right.$; Trenberth 1997$)$.

- The Atlantic Multi-decadal Oscillation (AMO, Figs. S2d-e) index, defined as the leading EOF of SST winter seasonal low-pass filtered anomalies (>13-yr; detrended) over the area $\left(0-70^{\circ} \mathrm{N}, 95^{\circ} \mathrm{W}-30^{\circ} \mathrm{E}\right.$; Mohino

- The Atlantic Meridional Overturning Circulation (AMOC, Fig. S2j) index, defined as the maximum streamfunction of the zonally integrated meridional overturning in the Atlantic Ocean $\left(30^{\circ} \mathrm{S}-60^{\circ} \mathrm{N}, 85^{\circ} \mathrm{W}-\right.$ $20^{\circ} \mathrm{E} ; 500-5700 \mathrm{~m}$ depth). A low pass filter is applied to the meridional velocity data (>13-yr) to retain the 
where $f$ is the Coriolis parameter, $N$ the static stability, $z$ the vertical coordinate and $v$ the horizontal wind vector.

\section{Cyclone Statistics}

A cyclone identification and tracking scheme (Murray and Simmonds 1991), adapted and validated for the Northern Hemisphere storm track (Pinto et al. 2005), is applied to 6-hourly winter (DJF) MSLP data. Cyclones are identified using the Laplacian of MSLP, an indicator of their geostrophic relative vorticity. Derived cyclone statistics compare well with other tracking schemes (Raible et al. 2008). Systems are selected based on the following criteria (Pinto et al. 2009): (i) cyclone lifetime $\geq 24$ h; (ii) minimum MSLP (p) < $1000 \mathrm{hPa}$; (iii) Max. $\left(\nabla^{2} \mathrm{p}\right)>0.6 \mathrm{hPa}$ deg.lat..$^{-2}$; and (iv) Max. $\mathrm{d} / \mathrm{dt} \nabla^{2} \mathrm{p} \geq 0.3 \mathrm{hPa}$ deg.lat. ${ }^{-2}$ day $^{-1}$. The maximum normalized deepening rate $(N D R)$ is used as a measure of cyclone's intensity (2):

$$
N D R=\frac{\Delta P}{24} \frac{\sin 60^{\circ}}{\sin \varnothing}
$$

where $\Delta P$ is the pressure fall (hPa) and $\Phi$ the mean latitude of the cyclone's surface centre over a period of 24 hours. Depending on their maximum $N D R$, cyclones are separated into two 2 different subsets: (i) explosive cyclones (EC; $N D R \geq 1$ Bergeron); and (ii) non explosive cyclones (NoEC; NDR $<1$ Bergeron). Cyclone trackdensities are constructed by counting the number of cyclones intercepting a circle of radius 7.5 deg.lat. for each grid point over time, providing combined information of cyclone numbers and track lengths.

\section{Statistics Tests}

Different methods are applied for statistical hypothesis testing (von Storch and Zwiers 1999): (i) a two tailed $t$ test that accounts for autocorrelation of the series (Bretherton et al. 1999); (ii) a $t$ test for a difference in mean; (iii) a Mann-Whitney U test; and (iv) a Fisher's test for a difference in variance. The confidence intervals chosen

\section{Explosive cyclone variability in the reanalysis data sets}

\section{A) Interannual variability of explosive cyclone tracks}

In this section an analysis of explosive cyclone variability is presented for both reanalysis datasets. We focus on NCEP reanalysis because it spans a longer time period, but ERA-40 results are also discussed where appropriate. The mean track densities of explosive (EC) and non-explosive (NoEC) cyclones are shown in Fig. 
1a (NCEP 1948-2011). For EC, a maximum extending from Newfoundland to Iceland is identified. This maximum is consistent with cyclogenesis over the region of strongest baroclinicity near the Gulf Stream (Sanders and Gyakum 1980; Hoskins and Valdes 1990) and subsequent intensification of the storms as they cross the jet (Uccellini 1990; Gilet et al. 2009; Rivière et al. 2013). For NoEC, the area of maximum density is shifted northeastward, extending between southeast Greenland, northwest of the British Isles and Scandinavia.

In order to characterize the variability of winter cyclone activity, the leading Empirical Orthogonal Function (EOF) of cyclone track density anomalies is determined for the entire North Atlantic $\left[20^{\circ}-80^{\circ} \mathrm{N} ; 90^{\circ} \mathrm{W}-40^{\circ} \mathrm{E}\right]$ using NCEP reanalysis (Fig. 1b). This analysis includes all cyclones, i.e., explosive and non-explosive systems. The EOF pattern is hereafter labeled with the subscript ${ }_{\mathrm{T}}$ (total). The leading pattern (All1 ${ }_{\mathrm{T}}$ ) represents a latitudinal shift of cyclone trajectories between Iceland and Western Europe. The leading EOF of 250-hPa zonal wind anomalies $\left(\mathrm{Jet} 1_{\mathrm{T}}\right)$ and the climatological jet are also overlaid in Fig. $1 \mathrm{~b}$. The Jet $1_{\mathrm{T}}$ pattern is consistent with the NAO variability, i.e., with a northward (southward) latitudinal displacement and intensification (weakening) of the extra-tropical jet during the positive (negative) phase. The spatial correspondence between $\mathrm{All1}_{\mathrm{T}}$ and Jet $1_{\mathrm{T}}$ latitudinal nodes is evident in Fig. 1b, and is consistent with the steering of cyclone trajectories by the NAO (e.g., Hurrell et al. 2003; Pinto and Raible 2012). The stronger track density center of action over Iceland (Fig. 1b) suggests increased cyclone activity over the sub-polar region in agreement with a positive NAO phase (Pinto et al. 2009).

The leading EOF of explosive cyclone tracks $\left(\mathrm{EC}_{\mathrm{T}}\right)$ is compared to Jet $1_{\mathrm{T}}$ and the jet core in Fig. 1c. The $\mathrm{EC}_{\mathrm{T}}$ pattern looks also related to the Jet1 $1_{\mathrm{T}}$ anomalies, but in this case the jet and NAO variability appear to intensify/weaken explosive cyclone activity along their climatological trajectories rather than change the cyclone pathways. This pattern is consistent with the NAO-induced changes in North Atlantic baroclinicity, which is stronger and broader under the NAO positive phase (Pinto et al. 2009). In addition, EC forming over Eastern North America typically cross the upper-level jet from the right-entrance to the left-exit regions, and explosively amplify (Uccellini 1990; Rivière et al. 2013). In contrast, a weaker, less extended and southerly displaced jet is obviously less efficient for explosive intensification.

For completeness, the second leading EOFs of all cyclones $\left(\mathrm{All} 2_{\mathrm{T}}\right)$ and explosive cyclones $\left(\mathrm{EC}_{2} \mathrm{~T}\right)$ are provided as supplementary material in Figs. S3a-b. All $2_{\mathrm{T}}$ represents a north to south dipole of cyclone trajectories between northern Europe and the Mediterranean (Fig. S3a). $\mathrm{EC} 2{ }_{\mathrm{T}}$ reveals a different pattern, with an intensification/extension of the explosive tracks between the east coast of the US and the British Isles, and a weakening northeast of Iceland (Fig. S3b). EC2 $2_{\mathrm{T}}$ is consistent with Jet $2_{\mathrm{T}}$ (250-hpa zonal wind EOF2), a large- 
scale configuration known to foster the occurrence of explosive cyclogenesis and storm families over Western and Central Europe (Fig. S3b; Hanley and Caballero 2012; Pinto et al. 2014).

All1 $1_{\mathrm{T}} / \mathrm{EC} 1_{\mathrm{T}}$ are significantly $\left(95 \%\right.$ confidence interval) correlated with $\mathrm{Jet} 1_{\mathrm{T}}(0.92 / 0.72)$, the $\mathrm{NAO}$ $(0.91 / 0.78)$ and the AO (0.78/0.63) for NCEP (Table 1). Likewise, $\mathrm{All} 2_{\mathrm{T}}$ and $\mathrm{EC} 2_{\mathrm{T}}$ also significantly correlate with Jet $2_{\mathrm{T}}$. Most of the spectral power for these modes is concentrated within the range of periods 1-11 yr. (Fig. S3c for EC1, not shown for the others). All the modes are well separated (Fig. S2d; North et al. 1982).

For comparison, the mean track density pattern and corresponding EOF modes of ALL1 $1_{\mathrm{T}} / \mathrm{ALL} 2_{\mathrm{T}}$, $\mathrm{EC} 1_{\mathrm{T}} / \mathrm{EC} 2_{\mathrm{T}}$, and Jet $1_{\mathrm{T}} / \mathrm{Jet} 2_{\mathrm{T}}$ are also calculated for 1957-2001 using ERA-40 (Fig. S4). The ERA-40 track density pattern (Fig. S4a) is very similar to NCEP, but with a greater total number of cyclone counts. This may be due to the higher horizontal resolution of ERA-40 (Pinto et al. 2005). The EOFs are also similar to NCEP (Fig. S4b-e) and represent the same variability (Table 1). The modes are well separated (Fig. S3d). In general terms, the linear correlation results between $\mathrm{EC} 1_{\mathrm{T}}$ and $\mathrm{Jet} 1_{\mathrm{T}}$ agree well in both reanalysis (Table 1), with slightly lower values for NCEP (ERA-40: 0.85; NCEP: 0.72). However, if the same time period is considered, the values are almost identical (NCEP: 0.83). Thus, in the next section this apparent time-evolving correlation is analyzed in more detail.

\section{B) Analysis of stationarity}

In order to assess the stationarity of the relation between the NAO and explosive cyclogenesis, 21-year running correlations between the leading Principal Components $(\mathrm{PCs})$ of $\mathrm{EC} 1_{\mathrm{T}}$ and $\mathrm{NAO}_{\mathrm{T}} / \mathrm{Jet}_{\mathrm{T}}$ are shown in Fig. 1d for NCEP and ERA-40. The analysis suggests a non-stationary link between the $\mathrm{NAO}_{\mathrm{T}} / \mathrm{Jet}_{\mathrm{T}}$ variability and $\mathrm{EC} 1_{\mathrm{T}}$ in $\mathrm{NCEP}$. Specifically, the $\mathrm{NAO}_{\mathrm{T}} / \mathrm{Jet} 1_{\mathrm{T}}$ influence on $\mathrm{EC} 1_{\mathrm{T}}$ is particularly weak at the beginning of the period, increases abruptly in the 60s and remains large to the late 90s (solid blue/red curves in Fig. 1d). In ERA40 (Fig. 1d; dashed blue/red curves), the time series are too short to detect any change in the correlation. Nevertheless, the ERA-40 results are consistent with NCEP between the $60 \mathrm{~s}$ and $90 \mathrm{~s}$.

In order to analyze possible dynamical differences between the two NCEP periods, EOFs are calculated independently for winters $1948-1962$ (labeled as 50 s; e.g. EC1 $1_{50 s} / \mathrm{Jet}_{50 \mathrm{~s}}$ ) and 1963-1997 (labeled as 80s). All EOFs are standardized with respect to the PC for the full period. Figs. 2a-b show that the leading mode of explosive cyclone track density is sensitive to the choice of period. The 1948-1962 EOF1 for explosive cyclones $\left(\mathrm{EC}_{500}\right.$; Fig. 2a) is constrained over the western North Atlantic, showing a strengthening/weakening of the cyclone tracks between Eastern North America and southern Greenland. The structure of the associated Jet $1_{50 \mathrm{~s}}$ 
depicts a latitudinal jet variability also constrained to the westernmost part of the basin (Fig. 2a). In contrast, the spatial structure of $\mathrm{EC}_{80 \mathrm{~s}}$ is similar to $\mathrm{EC} 1_{\mathrm{T}}(\mathrm{Fig} .2 \mathrm{~b})$ and explains more variability ( $40 \mathrm{vs.} 36 \%$ ). The $\mathrm{EC} 1_{80 \mathrm{~s}}$ pattern is centered over the northeastern North Atlantic, with a maximum over Iceland.

For the jet variability (Jet $1_{80 \mathrm{~s}}$; Fig. 2b), both latitudinal centers of action are stronger than for Jet $1_{50 \mathrm{~s}}$ (Fig. 2a) and span the entire North Atlantic basin, explaining a much larger fraction of variance (56 vs. $32 \%$ ). The z500 anomalies of each period are regressed on the corresponding EC PCs (Figs. 2c-d, respectively). A pattern consisting of three centers of action over the North Atlantic is found for the first period (1948-1962), with positive anomalies over the western sub-tropical North Atlantic and Western Europe, and a negative anomaly south-west of Greenland. In contrast, the second period (1963-1997) features a very clear NAO/AO hemispheric structure, with significant seesaw anomalies spanning over the whole North Atlantic.

Differences in the NAO patterns calculated independently for each period ( $\mathrm{NAO}_{50 \mathrm{~s}}$ vs. $\mathrm{NAO}_{80 \mathrm{~s}}$, Figs. 2e-f) are consistent with differences in the regressed z500 patterns (Moore et al. 2013). In particular, the sub-tropical NAO center of action appears weaker over the central North Atlantic in the first period, and two separated maxima are found over Eastern North America and Europe (Fig. 2e). The positive maximum over Europe may hinder the extension of cyclone tracks over the eastern North Atlantic in EC1 ${ }_{50 s}$ (Fig. 2a). The spatial correlation between $\mathrm{NAO}_{50 \mathrm{~s}}$ and $\mathrm{NAO}_{\mathrm{T}}$ is only 0.50 . These results are consistent with Raible et al. (2014), who provided evidence based on the 20CR reanalysis that the z500 teleconnectivity between Baffin Island and the western North Atlantic is dominant for the period 1940-1969 (cf. their Fig. 5b). For the second period, a very strong, extensive, zonally symmetric and eastward displaced NAO is observed (Fig. 2f), which is consistent with enhanced cyclone activity over the eastern sub-polar North Atlantic (Fig. 2b). This $\mathrm{NAO}_{80 \text { s }}$ pattern shows a much higher spatial correlation with the total period $\mathrm{NAO}_{\mathrm{T}}(0.86)$.

The winter SST anomalies of each period are also regressed on the EC PCs (Figs. 2g-h). A significant cooling over the sub-tropical and sub-polar North Atlantic is associated with the positive phase of EC1 ${ }_{80 \text { s }}$ (Fig. 2h), and with warming in the central part of the basin. This Atlantic SST tripole pattern is typical of the positive phase of the NAO, whose subtropical part is found to have predictive skill (Czaja and Frankignoul 1999; Rodríguez-Fonseca et al. 2006; Losada et al. 2007). The regressed SST pattern has the same sign over the winter equatorial Pacific and sub-tropical north Atlantic, as is well described in the literature (Fig. 2h; Wang 2002; Sung et al. 2013). During the 50's period, a stronger connection with the North Pacific SSTs is evident (Fig. 2g), which is consistent with previous analyses (Raible et al. 2001; 2004). Although based on few SST observations, 
it is striking that the positive relationship between the equatorial Pacific and the sub-tropical North Atlantic anomalies disappears during the 50 's period (Fig. $2 \mathrm{~g}$ ), coinciding with the decoupling between $\mathrm{NAO}$ and $\mathrm{EC} 1_{50 \mathrm{~s}}$.

\section{C) Impact of multi-decadal variability}

The possible influence of the lower-frequency multi-decadal variability on the connection between explosive cyclogenesis and the NAO is investigated based on the inter-decadal evolution of the jet and maximum Eady Growth Rate. The latter is an indicator of baroclinicity and potential cyclone growth (Hoskins and Valdes 1990). The climatological values of the jet intensity (u250) and Maximum Eady Growth Rate in the upper (500-300 hPa; bi400) and lower (850-700 hPa; bi775) troposphere are presented in Figs. 3a and S5a (NCEP). Both bi400 and bi775 overlap well with u250 (particularly bi400). The three variables are thus good estimators of the vertical environmental wind shear and potential growth of cyclones (e.g., Pinto et al. 2009). Differences between the two periods (1948-1962 vs. 1963-1997) are shown in Fig. 3b. The early period is characterized by a weaker jet and decreased baroclinicity (bi400) over large parts of the sub-polar North Atlantic compared with the second period, with more suitable conditions for cyclone formation over the sub-tropical North Atlantic. For the lower level baroclinicity (bi775; Fig. S5b), large differences are observed over western Greenland. The strong low level baroclinicity over Western Greenland during the first period might explain the deflected EC trajectories toward this region in the $\mathrm{EC}_{50 \text { s }}$ pattern (cf. Fig. 2a). In addition, no significant change in bi775 is observed over the sub-tropical North Atlantic between the two periods, in contrast with the bi400 results (cf. Figs. $3 \mathrm{~b}$ and S5b). The bi400 changes might be related to the modified intensity of the sub-tropical jet, which is confined to the upper troposphere.

To analyze the decadal jet and NAO variability for the NCEP period, a Hovmöller diagram of low-pass filtered (>33 yr.) u250 anomalies averaged between $100^{\circ} \mathrm{W}-20^{\circ} \mathrm{W}$, an index of the latitudinal location of the maximum positive jet anomalies and a multi-decadal NAO index are presented in Fig. 3c. The latter is shifted and rescaled to have the same mean and standard deviation as the latitude index. The period of low correlation between $\mathrm{EC} 1_{\mathrm{T}}$ and Jet1 $1_{\mathrm{T}} / \mathrm{NAO}_{\mathrm{T}}(1948-1962)$ is characterized by minimum values in the jet latitude index and in the decadal NAO, and by negative u250 anomalies spanning over the latitude band $40^{\circ}-60^{\circ} \mathrm{N}$ (Fig. $3 \mathrm{c}$ ). In contrast, a more intense and poleward shifted jet is observed during the latter period, together with a more positive decadal NAO.

The influence of inter-decadal changes in the ocean is analyzed through the winter SSTs and integrated (0- 

decadal Oscillation (AMO; Knight et al. 2005) is found over the North Atlantic. This is consistent with the observed out-of-phase relation between the EC-NAO/Jet running-correlations and the AMO index (Fig. 1d). be associated with a more negative AMO phase. Both changes could be driven by the AMOC (Sun et al. 2015), greenhouse gas forcing, or both (Woollings et al. 2012).

The difference in winter integrated temperature (0-300 m, T300) is shown in Fig. S5d as an indicator of changes in the ocean heat content above the thermocline. The emerging pattern seems consistent with the impacts of AMO and AMOC, with significant cooling in the tropics (Wang and Zhang 2013, cf. their Fig. 1). The inter-decadal changes between the 50s and $80 \mathrm{~s}$ in terms of the meridional T300 gradient ( $\delta$ yT300) are also depicted in Fig. S5d. Significant changes in $\delta y T 300$ are found over the tropical North Atlantic, but not over extratropical areas.

We hypothesize that decadal variations of the jet and the ocean may contribute to modulate inter-decadal changes in the interannual variability of explosive North Atlantic cyclones. However, the robustness of these results is difficult to establish given the short time series. In particular, it is not clear if the variability changes in EC activity are triggered by natural decadal variability of the climate system, anthropogenic climate change (e.g., the eastern NAO shift during the late $20^{\text {th }}$ century, a slowdown of the AMOC, etc.) or are just fortuitous. These facts put forward the necessity of using long control simulations in order to better infer a robust hypothesis about the mechanisms involved and characterize EC variability at longer timescales.

\section{Explosive cyclone variability in ECHAM5/MPIOM1}

\section{A) Multi-decadal variability of explosive cyclone tracks}

We next describe the variability of explosive cyclones in a 505-yr long control simulation with the ECHAM5/MPIOM1 coupled model. First, a broad overview of the multi-decadal cyclone variability is provided, which could not be analyzed with the shorter reanalysis data sets.

Cyclone track density GCM climatologies for EC and NoEC are shown in Fig. 4a. Just like NCEP (Fig. 1a), the maximum in EC activity is located between Newfoundland and Iceland. For NoEC, the shape and counts are also similar to NCEP over the North Atlantic. The main difference between ECHAM5 and NCEP for EC densities (Fig. 4b) is that ECHAM5 produces too zonal tracks - a systematic bias in GCMs (e.g., Zappa et al. 2014; Seiler and Zwiers 2015). The same is found for NoEC (not shown). 

variability at multi-decadal timescales are very similar to the unfiltered modes found for reanalysis (cf. section 4). In particular, $\mathrm{EC}_{\mathrm{LF}}$ (Fig. 4c; LF stands for low frequency) also represents a strengthening/weakening of EC tracks between Newfoundland and Iceland. EC2 $2_{\text {LF }}$ (Fig. S6a) depicts a similar pattern southerly shifted between eastern North America and Western Europe. The leading EOFs of low pass filtered (>11-yr) u250 winter anomalies reveal again very similar structures to the interannual modes. Please note the different scales used in Figs. 4 and S6 due to the different amplitude of this variability. (e.g., decadal NAO, AMO, IPO etc.) are provided in Table 2. Correlations show that $\mathrm{EC} 1_{\mathrm{LF}}$ is tightly connected with decadal variability of the NAO $\left(\mathrm{NAO}_{\mathrm{LF}} ; 0.75\right)$ and the jet $\left(\mathrm{Jet} 1_{\mathrm{LF}} ; 0.68\right)$. EC $2_{\mathrm{LF}}$ is significantly anticorrelated (correlated) with Jet $1_{\mathrm{LF}}\left(\mathrm{Jet} 2_{\mathrm{LF}}\right)$. These results suggest that multi-decadal fluctuations of EC tracks and frequencies are primarily controlled by the decadal variability of the NAO and the jet.

\section{B) Interannual variability of explosive cyclone tracks}

In order to test the robustness of the results from section 4, the interannual (1-11 yr.) variability of EC density tracks is also analyzed in ECHAM5/MPIOM1. The leading interannual EOF of explosive cyclones for the whole period $\left(\mathrm{EC1}_{\mathrm{T}}\right)$ represents a strengthening/weakening of the climatological pattern between Newfoundland and Iceland (Fig. 4d), also consistent with EOF1 of u250 (Jet1 $1_{\mathrm{T}}$ ).

The winter anomalies of z500 for the total ECHAM5 period are regressed on the $\mathrm{EC} 1_{\mathrm{T}} \mathrm{PC}(\mathrm{Fig}$. $4 \mathrm{e}$ ), revealing again a very clear AO/NAO pattern (cf. Table 1). This pattern is very similar to that obtained for the second NCEP period (Fig. 2d). The winter SST anomalies are also regressed on $\mathrm{EC1}_{\mathrm{T}} \mathrm{PC}$ (Fig. 4f), resulting in a pattern very similar to the second NCEP period (Fig. 2h). In particular, both the North Atlantic tripole pattern and ENSO appear to be significantly correlated and anti-correlated, respectively, with the leading mode of variability of explosive cyclone tracks. These results contrast with the non-significant ENSO-EC1 connection found in NCEP (Fig. 2h). However, as already mentioned, results from observations should be considered with caution due to the short time series of available data. agreement with NCEP and ERA-40. 

extent these results are caused by natural variability of the climate system, the time-dependent relation between $\mathrm{EC1}_{\mathrm{T}}$ and the $\mathrm{Jet}_{\mathrm{T}} / \mathrm{NAO}_{\mathrm{T}}$ variability is analyzed. We focus on the interannual (1-11 yr.) variability, as the spectral density of the reanalysis is mainly concentrated within the band 1-11 yr (cf. Fig. S3c). Fig. 5a shows the 21-yr running correlations between the principal components $(\mathrm{PCs})$ of $\mathrm{EC} 1_{\mathrm{T}}$ and the $\mathrm{NAO} \mathrm{T}_{\mathrm{T}} / \mathrm{Jet}_{\mathrm{T}}$. $\mathrm{EC} 1_{\mathrm{T}}$ and $\mathrm{NAO}_{\mathrm{T}}$ are highly correlated most of the time, but appear to be less correlated or 'decoupled' in specific periods. The same is found for $\mathrm{EC} 1_{\mathrm{T}} \mathrm{vs}$. Jet $1_{\mathrm{T}} \mathrm{PCs}$. Hereupon we refer to the periods of low correlation as 'decoupling periods' (51 years in total, model years 182-209 and 305-327; Fig. 5a). Although smoothed, the 'decoupling periods' can still be detected in the running correlations if the window length is increased to 41-yr.

We analyze the change of the leading patterns of variability during the simulation with running EOFs. If the EC or NAO variability changes during specific periods, the EOFs for those periods are expected to look differently. With this aim, we compute the EOFs in 21-yr sliding windows (485 patterns for 505 years) with a consistent polarity for all calculations.

On the one hand, the spatial correlation between each of the $485 \mathrm{NAO}$ patterns and the total period $\mathrm{NAO}_{\mathrm{T}}$ is shown in Fig. 5b. There are no abrupt changes in the correlations during the decoupling periods, suggesting that the NAO spatial structure could remain largely unchanged. However, visual inspection of the spatial NAO pattern calculated only for the decoupling dates (Fig. 5c; hereafter $\mathrm{NAO}_{\mathrm{D}}$ ) reveals a noticeable strengthening of its southern node compared with $\mathrm{NAO}_{\mathrm{T}}($ Fig. S1c). This is suggestive that the NAO spatial correlation values in Fig. $5 \mathrm{~b}$ could be more sensitive to the location of the NAO centers of action than to their relative strength. As will be described later on, the relative intensity of the NAO nodes and their projection onto the mean flow seems to be determinant for explosive cyclone development over the North Atlantic.

On the other hand, the spatial correlation between the time-varying and total-period explosive cyclone modes is non-stationary in time and changes abruptly during the decoupling periods (Fig. 5b). This suggests that the occurrence of the decoupling periods is due to a clearly different spatial structure of the leading EC variability. A zonal average $\left(90^{\circ} \mathrm{W}-40^{\circ} \mathrm{E}\right)$ of each of the $485 \mathrm{EC} 1$ regression patterns is performed to characterize these changes. An index with the latitudinal location of the maximum positive center of action for each EC1 pattern is displayed in Fig. 5b, and shows an abrupt southward shift of this center of action (from $\sim 60^{\circ} \mathrm{N}$ to $45^{\circ} \mathrm{N}$ ) during the decoupling periods. This is confirmed when the specific EOF1 of explosive cyclone track density anomalies is calculated solely for the decoupling dates $\left(\mathrm{EC} 1_{\mathrm{D}}\right.$; Fig. $\left.5 \mathrm{~d}\right)$. Here, $\mathrm{EC} 1_{\mathrm{D}}$ represents a strengthening/weakening of the explosive cyclone tracks between Eastern North America and Western Europe, a 
pattern shifted south relative to the total period $\mathrm{EC}_{\mathrm{T}}$ (compare Figs. $4 \mathrm{~d}$ and $5 \mathrm{~d}$ ). Finally, the corresponding

404

405

406

407

408

409

410

411

412

413

414

415

416

417

418

419

420

421

422

423

424

425

426

427

428

429

430

431 second leading EOF $(\mathrm{EC} 2 \mathrm{D}$ ) depicts an intensifying/weakening pattern more constrained over the Icelandic area (Fig. S6e). This suggests that the two leading EOFs change order during the decoupling periods.

Although the leading variability of EC track density is normally explained by a pattern confined over the northern sub-polar regions, the variability shifts south during specific periods and cannot be explained by the EOFs computed for the full period $\left(\mathrm{EC1}_{\mathrm{T}}\right.$ and $\left.\mathrm{NAO}_{\mathrm{T}}\right)$. Unlike $\mathrm{NCEP}$, these changes do not appear to be associated with a pure longitudinal shift of the NAO nodes, but with modifications in their relative strength. The potential changes in the interannual forcing during the decoupling periods are investigated through the regression of z500 and SST winter anomalies on EC1 $1_{\mathrm{D}}-\mathrm{PC}$ (Figs. 5e-f). During these periods, the z500 pattern associated with the variability of EC is characterized by a belt of low pressure anomalies extending from Newfoundland to Western Europe between $40^{\circ}-60^{\circ} \mathrm{N}$ (Fig. 5e). This anomaly is accompanied by positive anomalies of z500 between Greenland and Scandinavia and over the eastern sub-tropical North Atlantic $\left(\sim 30^{\circ} \mathrm{N}\right)$. The sign and shape of the z500 anomalies do resemble the NAO- pattern. Indeed, the correlation between $\mathrm{EC} 1_{\mathrm{D}}$ and Jet1 $1_{\mathrm{D}} / \mathrm{NAO}_{\mathrm{D}}$ is $-0.62 /-0.49$ (99\% confidence interval). Therefore, explosive cyclones appear to be favored by NAO- during the decoupling periods, in contrast with the normal situation. It will be shown in section $5 \mathrm{E}$ that the baroclinicity associated with the negative NAO years during the decoupling periods is stronger and more extensive over the North Atlantic than that for the positive NAO years (unlike the climatology; cf. Pinto et al. 2009). Regarding the SST anomalies, no significant regression pattern is found (Fig. $5 \mathrm{f})$, nor there is an indication of the North Atlantic SST tripole during the decoupling periods.

\section{D) Impact of multi-decadal variability}

The potential role of multi-decadal variability as modulator of interannual EC variability is analyzed in the following. During the decoupling periods, EC is anomalously frequent in the corridor between the eastern US and Western Europe, while their numbers are reduced from southern Greenland to Western Scandinavia (Fig. 6a). A similar structure is observed in the variance, with an increase of variability to the south and a decrease to the north. This is consistent with greater variability in the areas where EC are more frequent. In contrast, no significant differences are observed in the mean or in the variance of the North Pacific storm track (not shown). This suggests that the westerly flow from the North Pacific does not play an important role in the occurrence of the decoupling periods. 

are calculated for the decoupling periods. The climatological means for ECHAM5 are provided in Fig. $6 \mathrm{~b}$ for comparison. The overlapping between both variables is evident, although with a much more zonal structure than for NCEP. During the decoupling periods both the jet and bi400 significantly shift south (Fig. 6c), with positive anomalies over the sub-tropical North Atlantic and negative values over the Newfoundland-Iceland area. The same is observed for bi775 (not shown). Thus, the long-term upper-level conditions become more efficient for cyclone growth between the eastern US and Western Europe at the expense of the sub-polar North Atlantic.

The low-pass filtered ( $>33$-yr) u250 anomalies averaged between $100^{\circ}-20^{\circ} \mathrm{W}$ are used to highlight the latitude of the maximum positive jet anomalies in Fig. 6d. The decadal NAO index is also shown. The polar jet exhibits strong multi-decadal variability, with multiple oscillations in the latitude range $30^{\circ}-65^{\circ} \mathrm{N}$.

It is noticeable that both decoupling periods feature a persistent and remarkably equatorward shifted jet. Moreover, weakened upper-level winds are identified around $45^{\circ}-60^{\circ} \mathrm{N}$ (consistent with Fig. 6c). Although the low-frequency variability of the NAO and the jet appear similar in Fig. 6d, it is noteworthy that the decadal NAO index has lower amplitude during the decoupling periods. Therefore, additional potential forcings for the southward shift of the jet are investigated.

Eddy-driven jets tend to be located over areas with maximum meridional SST and ocean heat content (OHC; total heat content above the oceanic thermocline) gradients (cf. Figs. 7a and S7a; Minobe et al. 2008; Nakamura et al. 2008). Therefore, we hypothesize that if the North Atlantic SST/OHC meridional gradient shifts in latitude during specific periods, then the extra-tropical jet and baroclinicity fields might also respond to this forcing (Dong et al. 2013). This is observed for the SST and OHC anomaly during the decoupling periods (Fig. 7b). During these periods, an extensive cold SST anomaly is present across the sub-tropical North Atlantic. Such anomaly extends over the full mixed layer depth (Fig. 7b) and below the thermocline (Fig. S7b). As a consequence, a significant attenuation of the meridional OHC gradient is observed over the Gulf Stream area during the decoupling periods, together with an increase over the sub-tropical North Atlantic (Fig. 7c). Such a $\mathrm{SST} / \mathrm{OHC}$ anomaly pattern is thought to: (i) force positive jet and baroclinicity anomalies over the sub-tropical North Atlantic; and (ii) support the persistence of these anomalies through a positive feedback process. A southerly shifted storm track cools the waters beneath, which acts to reinforce the pre-existing SST anomaly (Dong et al. 2013). As a note of caution, it must be noted that these gradient anomalies (Fig. 7c) are particularly weaker than in Nakamura et al. (2008). To evaluate the potential forcing of these oceanic anomalies, several 
indices of temperature anomaly in the mixed layer are constructed for the North Atlantic area $\left(30^{\circ}-40^{\circ} \mathrm{N}, 60^{\circ}\right.$ -

463

464

465

466

467

468

469

470

471

472

473

474

475

476

477

478

479

480

481

482

483

484

485

486

487

488

489

490

491

$30^{\circ} \mathrm{W}$; dashed rectangle in Fig. $\left.7 \mathrm{~b}\right)$. Fig. $7 \mathrm{~d}$ shows the low pass filtered ( $\left.>33-\mathrm{yr}\right)$ indices of ocean temperature anomaly in depth. As expected, they reveal exceptional negative anomalies over the focus area during the decoupling periods. The AMOC index calculated for the MPIOM1 data is also provided in Fig. 7d (cf. AMOC pattern in Fig. S2j) and significantly correlates with the indices of ocean temperature anomaly: AMOC vs. SST $=0.35$; AMOC vs. T123m $=0.60(99 \%$ confidence interval $)$. However, the overlapping is not so evident for all the periods (e.g., second decoupling period). We speculate that the AMOC could play a role for the occurrence of the decoupling periods in agreement with an equatorward shift of the extra-tropical jet and baroclinicity, but the degree of this influence is uncertain. In this line, a deficient representation of the AMOC strength in climate models appears to lead to important SST biases over the North Atlantic (Wang et al. 2014). Despite the obtained AMOC pattern in ECHAM5/MPIOM1 looks strong enough (cf. Fig. S2j), the model bias could exert as well some undesired influence in the dynamics observed during the decoupling periods.

In the next section, we discuss possible atmospheric mechanisms explaining the changes in the NAO-EC relation during the decoupling periods based on these ingredients.

\section{E) Potential mechanisms leading to the Decoupling Periods}

In this section, we propose two different mechanisms to explain the abrupt transitions in the EC leading variability and its connection with the NAO.

- The cross-jet mechanism: Under normal conditions, the interannual jet alternates its position between the northern, central and southern North Atlantic locations during consecutive years (Fig. 8a; Woollings et al. 2010). When the jet is situated over its northern position (NAO+), low pressure systems forming over eastern North America can easily cross the extra-tropical jet and explosively amplify (Fig. 8a; cf. Uccellini 1990; Gilet et al. 2009; Rivière et al. 2013). Under a negative NAO phase, the relative position between developing cyclones and the jet is less efficient for rapid cyclone intensification, and explosive cyclone deepening is thus weaker over the North Atlantic. This mechanism is consistent with the NAO modulation of explosive cyclone variability identified for most of the time periods in the GCM. However, when the interannual jet is persistently (20-25 yr.) located over the central or sub-tropical North Atlantic (i.e. a southerly shifted multi-decadal jet), the EC variance associated with $\mathrm{NAO}+$ years is absent. This implies that $\mathrm{NAO}+$ no longer acts as a precursor for explosive cyclone deepening; instead, a different mode of 

vary with the NAO phase but the main genesis area of explosive cyclones over Eastern North America must not, which is the case in our results (cf. Figs. 8ab). Thus, we consider the cross-jet mechanism as a plausible hypothesis for the occurrence of abrupt transitions in the EC variability and the decoupling periods. configurations would be useful. Such an approach is outside the scope of the paper and is left for future work.

517

\section{Summary and conclusions}

This study explores the modulating role of the multi-decadal oceanic and atmospheric variability ( $>11-\mathrm{yr})$ on the interannual climate variability (1-11 yr.) of explosive cyclogenesis over the North Atlantic in wintertime. In addition, the multi-decadal variability of explosive cyclone tracks is assessed. For this purpose, the track density 
of explosive and non-explosive cyclones from two reanalysis datasets and a long control General Circulation Model (GCM) simulation are analyzed. An Empirical Orthogonal Function (EOF) approach is used to characterize the preferred modes of variability in the North Atlantic.

Results show that the leading mode of the interannual climate variability for all cyclones (All1 ${ }_{\mathrm{T}}$ ) represents primarily a latitudinal shift of cyclone trajectories between Iceland and Western Europe (Fig. 1b). This pattern is consistent with previous studies (e.g., Rogers 1997; Lu and Greatbach 2002). However, the leading interannual variability mode of explosive cyclone tracks $\left(\mathrm{EC}_{\mathrm{T}}\right)$ consists of a strengthening/weakening of its climatological pattern extending from Newfoundland to Iceland (Fig. 1c). Although these two patterns are different, both modes are significantly correlated with the North Atlantic Oscillation (NAO) during most time periods in all three datasets (cf. Table 1). This results from the influence of the NAO in modulating cyclone's trajectories (All1 $\mathrm{T}$; cf. Wanner et al. 2001) and cyclone intensification rates (EC1 $1_{\mathrm{T}}$; cf. Pinto et al. 2009). However, during specific decades of NCEP and ECHAM5, the EC1-NAO correlation abruptly drops.

For NCEP, this non-stationary relationship is apparently associated with multi-decadal changes in the NAO shape and location. In particular, the NAO-EC1 correlation is 0.68 between 1948 and 1962. In this period the NAO pattern is more confined over the western North Atlantic (Raible et al. 2014). Contrastingly, the period 1963-1997 is characterized by an eastward extension and intensification of the NAO centers of action (Jung et al. 2003). During this period, the NAO-EC1 correlation increases to 0.89 . The changes in the NAO structure are consistent with the changes in EC1 between periods. Thus, EC1 is more confined west in the basin during the mid $20^{\text {th }}$ century, whereas for recent decades it appears stronger and more extended towards Northern Europe (cf. Fig. 2). These decadal changes in NAO and EC1 variability appear to coincide with changes in the Atlantic Multi-decadal Oscillation phase (AMO; Woollings et al. 2012).

For ECHAM5, the NAO-EC1 correlation is constant and positive during most of the simulation, except for two periods about 20-25 yr. long (Fig. 5). During these periods (so called 'decoupling periods'), EC1 abruptly changes shape and the NAO-EC1 correlation rapidly switches to negative values. In this article two different potential mechanisms have been proposed to explain such behavior:

- The first is the so called cross-jet mechanism and relies on the relative position between the eddydriven jet (Woollings et al. 2010) and explosive cyclones growing over eastern North America (Hoskins and Hodges, 2002) during consecutive years (20-25 yr.). This mechanism appears to be related to multi-decadal variability of the atmosphere and the ocean. It occurs during periods when the jet is persistently shifted south, the meridional gradient of ocean heat content over the 
subtropical North Atlantic is enhanced and the Atlantic Meridional Overturning Circulation (AMOC) is weakened (Figs. 6 to 8).

- The second is the so called NAO-baroclinicity mechanism. This mechanism relies on multi-decadal variability of the atmosphere, in particular on how multi-decadal changes in the NAO structure and relative strength of its centers of action project on interannual variability features. As opposed to climatology (Pinto et al. 2009), the baroclinicity associated with NAO- is stronger and more extensive than for $\mathrm{NAO}+$ over the North Atlantic during the decoupling periods (Figs. 9 and 10). As a consequence, explosive cyclones are favored by NAO- instead of NAO+. These changes lead to abrupt transitions in the EC leading variability mode and the EC1-NAO correlation.

The present results evidence the importance of the low-frequency control for the time-evolving interannual climate variability of explosive cyclone tracks in the North Atlantic. This modulation leads to a non-stationary connection between the NAO and EC activity both in reanalysis and GCM data. In this context, a plausible influence of the ocean circulation on this non-stationary connection is highlighted. Although this influence looks different between reanalysis and the GCM, this is not surprising as the low NAO-EC1 correlation periods in both datasets are associated with distinct EOF patterns (compare Figs. 2a and 5d). An interesting question left for future work concerns the relative role played by the ocean in the longitudinal location and relative intensity of the NAO centers of action (Wang et al. 2012; Raible et al. 2014). The opposite effect, in which the NAO triggers multi-decadal changes in the ocean, is also present in the literature (Visbeck et al.1998; Delworth and Greatbatch 2000; Eden and Jung 2001). The NAO positive phase is thought to strengthen the AMOC via air-sea fluxes of heat and momentum (Delworth and Zeng 2015), and induce a basin-wide SST warming (AMO pattern). This pattern subsequently switches phase and behaves as a delayed oscillator, which explains a $60 \mathrm{yr}$. quasi-periodic cycle of the NAO (Sun et al. 2015). In this work we suggest that AMOC could in turn alter the position of the jet stream and maximum baroclinicity over the North Atlantic, thus modifying the preferred regions explosive cyclone development. The study of the opposite branch of this relation remains as an interesting path for future research.

The present results can potentially contribute to an improvement of the multi-decadal predictions of extreme cyclones in the North Atlantic (e.g., Lee et al. 2012; Nissen et al. 2014; Feser et al. 2015). Regarding the potential role of anthropogenic climate change in the NCEP results, it must be noted that abrupt changes in the variability of explosive cyclogenesis are also observed in the pre-industrial simulation, so these transitions can be internally driven. 

also found in the GCM data (Luksch et al. 2005). Such connection must be checked in additional control

584 simulations to potentially improve seasonal predictions of explosive North Atlantic cyclones.

585 At multi-decadal timescales (>11-yr), the main variability mode of explosive cyclones also depicts a strengthening/weakening pattern of EC tracks between Newfoundland and Iceland (Fig. 4c). Our results suggest that this variability is predominantly driven by the decadal NAO and jet variability. Further analysis on this topic is also left for future work.

589 Finally, as this study is mainly focused on explosive cyclogenesis, an extended analysis for all cyclones and their time-varying relation with the NAO will be an interesting path for future research through the use of a larger set of control and forced simulations (e.g., CMIP5 models).

592

\section{Acknowledgements}

594 We thank the National Centers for Environmental Prediction and the European Centre for Medium-Range 595 Weather Forecasts for the NCEP and ERA-40 reanalysis. We thank the Met Office Hadley Centre for the SST 596 and sea ice data (HadISST) and the University of Maryland for the Simple Ocean Data Assimilation (SODA) 597 reanalysis. We are indebted to the Max Plank Institute and the Deutsches Klimarechenzentrum (DKRZ) for the 598 ECHAM5/MPIOM1 data. In particular, we thank Hans Winter, Hannes Thiemann, Helmuth Haak and Monika 599 Esch for help with the MPIOM1 data. IG is supported by the research projects MULCLIVAR (CGL-2012600 38923-C02-01 - Spanish Ministry of Economy and Competitiveness) and PREFACE (EUFP7/2007-2013 grant agreement 603521). We thank Irene Polo, Marta Martín-Rey, Jorge López-Parages, Rubén Banderas, Tim

602 Woollings and Christoph Raible for constructive remarks. We thank Gwendal Rivière and another anonymous 603 reviewer for their pertinent comments and suggestions, which have contributed to improve this manuscript. 


\section{References}

Bader J, Mesquita MDS, Hodges KI, Miles M, Osterhus S, Keenlyside N (2011) A Review on Northern Hemisphere Sea-Ice, Storminess and the North Atlantic Oscillation: Observations and Projected Changes. Atmos Res 101: 809-834. doi:10.1016/j.atmosres.2011.04.007 .

Baldwin MP, Dunkerton TJ (2001) Stratospheric Harbingers of Anomalous Weather Regimes. Science 294 (5542): 581-584. DOI:10.1126/science. 1063315

Barnston AG, Livezey RE (1987) Classification, Seasonality and Persistence of Low-Frequency Atmospheric Circulation Patterns. Mon Wea Rev 115: 1083-1126. doi: 10.1175/15200493(1987)115<1083:CSAPOL>2.0.CO;2

Benedict JJ, Lee S, Feldstein SB (2004) Synoptic view of the North Atlantic Oscillation. J Atmos Sci 61: 121 144.

Bengtsson L, Hodges KI, Roeckner E, Brokopf R (2006) On the natural variability of the pre-industrial European climate. Clim Dyn 27:743-760.

Bjerknes J, Solberg H (1922) On the life cycle of cyclones and the polar front theory of atmospheric circulation (edited by Henry AJ). Mon Wea Rev 50: 468-473. doi: http://dx.doi.org/10.1175/15200493(1922)50<468:JBAHSO>2.0.CO;2

Blackmon ML, Wallace JM, Lau NC, Mullen SL (1977) An Observational Study of the Northern Hemisphere Wintertime Circulation. J Atmos Sci 34: 1040-1053. doi: 10.1175/15200469(1977)034<1040:AOSOTN>2.0.CO;2

Bosart LF, Lin SC (1984) A diagnostic analysis of the Presidents' Day storm of February 1979. Mon Wea Rev 112: $2148-2177$.

Bretherton CS, Widmann M, Dymnikov VP, Wallace JM, Blade I (1999) Effective number of degrees of freedom of a spatial field. J Climate 12: 1990-2009.

Carton JA, Giese BS (2008) A Reanalysis of Ocean Climate Using Simple Ocean Data Assimilation (SODA). Mon Wea Rev 136: 2999-3017

Chang EKM, Orlanski I (1993) On the Dynamics of a Storm Track. J Atmos Sci 50: 999-1015. doi: 10.1175/1520-0469(1993)050<0999:OTDOAS >2.0.CO;2

Chen S, Wu R, Chen W (2015) The Changing Relationship between Interannual Variations of the North Atlantic Oscillation and Northern Tropical Atlantic SST. J Climate 28: 485-504. doi: 10.1175/JCLI-D-1400422.1 
Czaja A, Frankignoul C (1999) Influence of the North Atlantic SST on the atmospheric circulation. Geophys Res Lett 26 (19): 2969-2972. DOI: 10.1029/1999GL900613

Davis CA, Emanuel KA (1988) Observational evidence for the influence of surface heat fluxes on maritime cyclogenesis. Mon Wea Rev 116: 2649 - 2659.

Delworth TL, Greatbatch RJ (2000) Multidecadal thermohaline circulation variability driven by atmospheric surface flux forcing. J Clim 13: 1481-1495.

Delworth T, Zeng F (2015) The impact of the North Atlantic Oscillation on climate through its influence on the Atlantic Meridional Overturning Circulation. J Clim. doi:10.1175/JCLI-D-15-0396.1

Dong B, Sutton RT, Woollings T, Hodges K (2013) Variability of the North Atlantic summer storm track: mechanisms and impacts on European climate. Environ Res Lett 8: 034037. doi:10.1088/1748$9326 / 8 / 3 / 034037$

Drouard M, Rivière G, Arbogast P (2015) The Link between the North Pacific Climate Variability and the North Atlantic Oscillation via Downstream Propagation of Synoptic Waves. J Climate 28: 3957-3976. doi: 10.1175/JCLI-D-14-00552.1

Eden C, Jung T (2001) North Atlantic interdecadal variability: oceanic response to the North Atlantic Oscillation (1865-1997). J Clim 14: 676-691.

Feldstein SB (2003) The dynamics of NAO teleconnection pattern growth and decay. Q J R Meteorol Soc 129: 901-924.

Feser F, Barcikowska M, Krueger O, Schenk F, Weisse R, Xia L (2015) Storminess over the North Atlantic and northwestern Europe-A review. Q J R Meteorol Soc 141: 350-382. doi: 10.1002/qj.2364

Fink AH, Pohle S, Pinto JG, Knippertz P (2012) Diagnosing the influence of diabatic processes on the explosive deepening of extratropical cyclones. Geophys Res Lett 39: L07803. doi:10.1029/2012GL051025.

Fosdick EK, Smith PJ (1991) Latent Heat Release in an Extratropical Cyclone that Developed Explosively over the Southeastern United States. Mon Wea Rev 119: 193-207.

Gilet JB, Plu M, Rivière G (2009) Nonlinear baroclinic dynamics of surface cyclones crossing a zonal jet. J Atmos Sci 66: 3021-3041.

Gómara I, Pinto JG, Woollings T, Masato G, Zurita-Gotor P, Rodríguez-Fonseca B (2014a) Rossby WaveBreaking analysis of Explosive Cyclones in the Euro-Atlantic sector. Q J R Meteorol Soc 140: 738-753. . doi: $10.1002 /$ qj.2190 
Gómara I, Rodríguez-Fonseca B, Zurita-Gotor P, Pinto JG (2014b) On the relation between explosive cyclones affecting Europe and the North Atlantic Oscillation. Geophys Res Lett 41: 2182-2190. doi:10.1002/2014GL059647.

Gyakum JR, Danielson RE (2000) Analysis of meteorological precursors to ordinary and explosive cyclogenesis in the western North Pacific. Mon Wea Rev 128: 851 - 863.

Hanley J, Caballero R (2012) The role of large-scale atmospheric flow and Rossby wave breaking in the evolution of extreme windstorms over Europe. Geophys Res Lett 39: L21708, doi:10.1029/2012GL053408

Hoerling MP, Hurrell JW, Xu T (2001) Tropical origin for recent North Atlantic climate change. Science 292: 90- 92

Hoerling MP, Hurrell JW, Xu T, Bates GT, Phillips A (2004) Twentieth century North Atlantic climate change. Part II: Understanding the effect of Indian Ocean warming. Clim Dyn 23: 391-405, doi:10.1007/s00382-004-0433-x

Honda M, Nakamura H, Ukita J, Kousaka I, Takeuchi K (2001) Interannual Seesaw between the Aleutian and Icelandic Lows. Part I: Seasonal Dependence and Life Cycle. J Climate 14: 1029-1042. doi: 10.1175/15200442(2001)014<1029:ISBTAA>2.0.CO;2

Hoskins BJ, McIntyre ME, Robertson AW (1985) On the use and significance of isentropic potential vorticity maps. Q J R Meteorol Soc 111: 877-946.

Hoskins BJ, Valdes PJ (1990) On the Existence of Storm-Tracks. J Atmos Sci 47: 1854-1864. doi: 10.1175/1520-0469(1990)047<1854:OTEOST>2.0.CO;2

Hoskins BJ, Hodges KI (2002) New perspectives on the Northern Hemisphere winter storm tracks. J. Atmos. Sci., 59 (6), 1041-1061.

Hurrell JW, Kushnir Y, Ottersen G, Visbeck M (2003) The North Atlantic Oscillation: climate significance and environmental impact. Geophys. Monogr. Series 134: 279pp.

James IN, James PM (1989) Ultra-low-frequency variability in a simple atmospheric circulation model. Nature 342: 53-55

Jung T, Hilmer M, Ruprecht E, Kleppek S, Gulev SK, Zolina O (2003) Characteristics of the Recent Eastward Shift of Interannual NAO variability. J Clim 16:3371-3382.

Jungclaus JH, Botzet M, Haak H, Keenlyside N, Luo JJ, Latif M, Marotzke J, Mikolajewicz U, Roeckner E (2006) Ocean circulation and tropical variability in the coupled model ECHAM5/MPI-OM. J Clim 19:3952-3972. 
Kalnay E, and co-authors (1996) The NCEP/NCAR 40-Year Reanalysis Project, Bull the Am Meteorol Soc 77:

696

697

698

699

700

701

702

703

704

705

706

707

708

709

710

711

712

713

714

715

716

717

718

719

720

721

722

723 437-471.

Knight JR, Allan RJ, Folland CK, Vellinga M, Mann ME (2005) A signature of persistent natural thermohaline circulation cycles in observed climate. Geophys Res Lett 32: L20708. doi:10.1029/2005GL024233.

Lau NC (1978) On the Three-Dimensional Structure of the Observed Transient Eddy Statistics of the Northern Hemisphere Wintertime Circulation. J Atmos Sci 35: 1900-1923. doi: 10.1175/15200469(1978)035<1900:OTTDSO>2.0.CO;2

Lau NC (1988) Variability of the Observed Midlatitude Storm Tracks in Relation to Low-Frequency Changes in the Circulation Pattern. J Atmos Sci 45: 2718-2743. doi: http://dx.doi.org/10.1175/15200469(1988)045<2718:VOTOMS >2.0.CO;2

Lee SS, Lee JY, Wang B, Ha KJ, Heo KY, Jin FF, Straus DM, Shukla J (2012) Interdecadal changes in the storm track activity over the North Pacific and North Atlantic. Clim Dyn 39: 313-327. doi: 10.1007/s00382-011-1188-9

López-Parages J, Rodríguez-Fonseca B (2012) Multidecadal modulation of El Niño influence on the EuroMediterranean rainfall. Geophys Res Lett 39: L02704. doi:10.1029/2011GL050049.

Losada T, Rodríguez-Fonseca B, Mechoso CR, Ma HY (2007) Impacts of SST anomalies on the North Atlantic atmospheric circulation: a case study for the northern winter 1995/1996. Clim Dyn 29 (7-8): 807-819.

Losada T, Rodriguez-Fonseca B, Mohino E, Bader J, Janicot S, Mechoso CR (2012) Tropical SST and Sahel rainfall: A non-stationary relationship. Geophys Res Lett 39: L12705 doi:10.1029/2012GL052423.

Lu J, Greatbatch RJ (2002) The changing relationship between the NAO and northern hemisphere climate variability. Geophys Res Lett 29 (7) doi: 10.1029/2001GL014052.

Luksch U, Raible CC, Blender R, Fraedrich K (2005) Decadal Cyclone Track Variability in the North Atlantic. Metorol Z special issue 14:747-753.

Marshall J, and coauthors (2001) North Atlantic climate variability: Phenomena, impacts and mechanisms. Int J Climatol 21: 1863-1898.

Messori G, Caballero R (2015) On double Rossby wave breaking in the North Atlantic. J Geophys Res Atmos 120: 11,129-11,150. doi:10.1002/2015JD023854.

Minobe S, Kuwano-Yoshida A, Komori N, Xie SP, Small RJ (2008) Influence of the Gulf Stream on the troposphere. Nature 452 (7184): 206-209 
Mohino E, Janicot S, Bader J (2011) Sahel rainfall and decadal to multi-decadal sea surface temperature variability. Climate Dynamics 37(3):419-440. DOI:10.1007/s00382-010-0867-2

Moore GWK, Renfrew IA, Pickart RS (2013) Multidecadal mobility of the North Atlantic Oscillation, J Climate 26: 2453-2466.

Müller WA, Frankignoul C, Chouaib N (2008). Observed decadal tropical Pacific-North Atlantic teleconnections. Geophys Res Lett 35: L24810. doi:10.1029/2008GL035901

Murray RJ, Simmonds I (1991) A numerical scheme for tracking cyclone centers from digital data. Part I: development and operation of the scheme. Aust Meteor Mag 39: 155-166.

Nakamura H, Sampe T, Goto A, Ohfuchi W, Xie SP (2008) On the importance of mid-latitude oceanic frontal zones for the mean state and dominant variability in the tropospheric circulation. Geophys Res Lett 35. doi:10.1029/2008GL034,010

Nissen KM, Ulbrich U, Leckebusch GC, Kuhnel I (2014) Decadal windstorm activity in the North AtlanticEuropean sector and its relationship to the meridional overturning circulation in an ensemble of simulations with a coupled climate model. Clim Dyn 43(5-6): 1545-1555. doi:10.1007/s00382-013-1975-6

North GR, Bell TL, Cahalan RF, Moeng FJ (1982) Sampling errors in the estimation of empirical orthogonal functions. Mon Wea Rev 110: 699-706. doi:10.1175/1520-0493(1982)110<0699:SEITEO> 2.0.CO;2

Osborn TJ, Briffa KR, Tett SFB, Jones PD, Trigo RM (1999) Evaluation of the North Atlantic oscillation as simulated by a coupled climate model. Clim Dyn 15:685-702.

Petterssen S, Smebye SJ (1971) On the development of extratropical cyclones. Q J R Meteorol Soc 97: 457482. doi: 10.1002/qj.49709741407

Pinto JG, Spangehl T, Ulbrich U, Speth P (2005) Sensitivities of cyclone detection and tracking algorithm: individual tracks and climatology. Meteorol Z 14: 823-838.

Pinto JG, Zacharias S, Fink AH, Leckebusch GC, Ulbrich U (2009) Factors contributing to the development of extreme North Atlantic cyclones and their relationship with the NAO. Clim Dyn 32: 711-737.

Pinto JG, Reyers M, Ulbrich U (2011) The variable link between PNA and NAO in observations and in multicentury CGCM simulations. Clim Dyn 36 (1-2): 337-354. doi: 10.1007/s00382-010-0770-x

Pinto JG, Raible CC (2012) Past and recent changes in the North Atlantic oscillation. Wiley Interdisciplinary Reviews: Climate Change 3: 79-90. doi:10.1002/wcc.150 
Pinto JG, Gómara I, Masato G, Dacre HF, Woollings T, Caballero R (2014) Large-scale dynamics associated with clustering of extratropical cyclones affecting Western Europe. J Geophys Res Atmos 119, 13,70413,719, doi:10.1002/2014JD022305.

Raible CC, Luksch U, Fraedrich K, Voss R (2001) North Atlantic decadal regimes in a coupled GCM simulation. Clim Dyn 18: 321-330

Raible CC, Luksch U, Fraedrich K (2004) Precipitation and Northern Hemisphere Regimes. Atmos Sci Lett 5: 43-55, DOI: 10.1016/j.atmoscilet.2003.12.001

Raible CC, Stocker TF, Yoshimori M, Renold M, Beyerle U, Casty C, Luterbacher J (2005) Northern Hemispheric trends of pressure indices and atmospheric circulation patterns in observations, reconstructions, and coupled GCM simulations. J Climate 18: 3968-3982

Raible CC, Della-Marta P, Schwierz C, Wernli H, Blender R (2008) Northern Hemisphere extratropical cyclones: A comparison of detection and tracking methods and different reanalyses. Mon Wea Rev 136: 880-897.

Raible CC, Lehner F, Gonzalez-Rouco JF, Fernandez-Donado L (2014) Changing correlation structures of the Northern Hemisphere atmospheric circulation from 1000 to 2100 AD, Climate of the Past 10: 537-550, doi:10.5194/cp-10-537-2014.

Rayner NA, Parker DE, Horton EB, Folland CK, Alexander LV, Rowell DP, Kent EC, Kaplan A (2003) Global analyses of sea surface temperature, sea ice, and night marine air temperature since the late nineteenth century. J Geophys Res 108 (14): 4407. doi: 10.1029/2002JD002670

Reader MC, Moore GWK (1995) Stratosphere-troposphere interactions associated with a case of explosive cyclogenesis in the Labrador Sea. Tellus A 47: 849-863.

Reichler T, Kim J, Manzini E, Kröger J (2012) A stratospheric connection to Atlantic climate variability. Nature Geoscience 5: 783-787. doi:10.1038/ngeo1586.

Rivière G, Joly A (2006) Role of the low-frequency deformation field on the explosive growth of extratropical cyclones at the jet exit. Part I: Barotropic critical region. J Atmos Sci 63: 1965-1981.

Rivière G, Gilet JG, Oruba L (2013) Understanding the Regeneration Stage Undergone by Surface Cyclones Crossing a Midlatitude Jet in a Two-Layer Model. J Atmos Sci 70: 2832-2853. doi: http://dx.doi.org/10.1175/JAS-D-12-0345.1

Rodríguez-Fonseca B, Polo I, Serrano E, Castro M (2006) Evaluation of the North Atlantic SST forcing on the European and North African winter climate. Int J Climatol 26:179-191. DOI: 10.1002/7joc.1234 
Rodríguez-Fonseca B, Polo I, García-Serrano J, Losada T, Mohino E, Mechoso CR, Kucharski F (2009) Are Atlantic Niños enhancing Pacific ENSO events in recent decades? Geophys Res Lett 36: L20705. doi:10.1029/2009GL040048.

Roeckner E, and coauthors (2003) The atmospheric general circulation model ECHAM 5. PART I: model description. MPI Report 349.

Rogers JC (1997) North Atlantic Storm Track Variability and Its Association to the North Atlantic Oscillation and Climate Variability of Northern Europe. J Climate 10 1635-1647. doi: 10.1175/15200442(1997)010<1635:NASTVA>2.0.CO;2

Sanders F, Gyakum JR (1980) Synoptic-Dynamic climatology of the bomb. Mon Wea Rev 108: 1589-1606.

Sanders F (1986) Explosive cyclogenesis in the west-central North Atlantic Ocean. Part I: Composite structure and mean behavior. Mon Wea Rev 114: 1781-1794.

Santos JA, Woollings T, Pinto JG (2013) Are the Winters 2010 and 2012 Archetypes Exhibiting Extreme Opposite Behavior of the North Atlantic Jet Stream? Mon Wea Rev 141: 3626-3640. doi: http://dx.doi.org/10.1175/MWR-D-13-00024.1.

Schneider EK, Bengtsson L, Hu ZZ (2003) Forcing of Northern Hemisphere climate trends. J Atmos Sci 60: $1504-1521$

Seiler C, Zwiers FW (2015) How well do CMIP5 climate models reproduce explosive cyclones in the extratropics of the Northern Hemisphere? Clim Dyn. doi: 10.1007/s00382-015-2642-x

Shapiro MA, Keyser D (1990) Extratropical Cyclones: The Erik Palmen memorial volume, chapter 10. Amer. Meteorol. Soc.

Shindell DT, Schmidt GA, Mann ME, Rind D, Waple A (2001) Solar forcing of regional climate change during the Maunder Minimum. Science 294: 2149-2152. doi:10.1126/science.1064363.

Stephenson DB, Pavan V, Bojariu R (2000) Is the North Atlantic Oscillation a random walk? Int J Climatol $20: 1-18$

Strong C, Magnusdottir G (2008) How Rossby wave breaking over the Pacific forces the North Atlantic Oscillation. Geophys Res Lett 35: L10706. doi: 10.1029/2008GL033578.

Sun C, Li J, Jin F (2015) A delayed oscillator model for the quasi-periodic multidecadal variability of the NAO. Clim Dyn 45: 2083-2099. doi: 10.1007/s00382-014-2459-z. 
Sung MK, Ham YG, Kug JS, An SI (2013) An alterative effect by the tropical North Atlantic SST in intraseasonally varying El Nino teleconnection over the North Atlantic. Tellus A 65: 19863. doi: http://dx.doi.org/10.3402/tellusa.v65i0.19863

Trenberth KE (1997) The Definition of El Niño. Bull the Am Meteorol Soc 78: 2771-2777.

Trenberth KE, Branstator GW, Karoly D, Kumar A, Lau NC, Ropelewski C (1998) Progress during TOGA in understanding and modeling global teleconnections associated with tropical sea surface temperatures. $\mathbf{J}$ Geophys Res, 103(C7): 14,291-14,324. doi:10.1029/ 97JC01444.

Trigo IF (2006) Climatology and interannual variability of storm-tracks in the Euro-Atlantic sector: a comparison between ERA-40 and NCEP/NCAR reanalyses. Clim Dyn 26: 127-143.

Uccellini LW (1990) Processes contributing to the rapid development of extratropical cyclones. Extratropical Cyclones: The Erik Palmen Memorial Volume, C. Newton and E. O. Holopainen, Eds., American Meteorological Society, 81-105.

Ulbrich U, Christoph M (1999) A shift of the NAO and increasing storm track activity over Europe due to anthropogenic greenhouse gas forcing. Clim Dyn 15:551-559

Uppala SM, and co-authors (2005) The ERA-40 re-analysis. Q J R Meteorol Soc 131: 2961-3012.

Vicente-Serrano SM, López-Moreno JI (2008) Differences in the non-stationary influence of the North Atlantic Oscillation on European precipitation under different scenarios of greenhouse gas concentrations. Geophys Res Lett 35: L18710. doi:10.1029/2008GL034832.

Villamayor J, Mohino E (2015) Robust Sahel drought due to the Interdecadal Pacific Oscillation in CMIP5 simulations. Geophys Res Lett 42: 1214-1222. doi: 10.1002/2014GL062473.

Visbeck M, Cullen H, Krahmann G, Naik N (1998) An ocean model's response to North Atlantic Oscillation like wind forcing. Geophys Res Lett 25: 4521-4524.

Visbeck M, Chassignet E, Curry R, Delworth T, Dickson B, Krahmann G (2003) The Ocean's response to North Atlantic oscillation variability. In: Hurrell, J.W., Kushnir, Y., Ottersen, G., Visbeck, M. (Eds.), The North Atlantic Oscillation. AGU, pp. 113-146.

von Storch H, Zwiers F (1999) Statistical analysis in Climate research Cambridge University press, Cambridge Wang C (2002) Atlantic Climate Variability and Its Associated Atmospheric Circulation Cells. J Climate 15: 1516-1536. doi: 10.1175/1520-0442(2002)015<1516:ACVAIA>2.0.CO;2 

Atlantic: Linking with the AMO, AMOC, and Subtropical Cell. J Climate 26: 6137-6162. doi: http://dx.doi.org/10.1175/JCLI-D-12-00721.1

Wang C, Zhang L, Lee SK, Wu L, Mechoso CR (2014) A global perspective on CMIP5 climate model biases. Nature Climate Change 4: 201-205.

Wang YH, Magnusdottir G, Stern H, Tian X, Yu Y (2012) Decadal variability of the NAO: Introducing an augmented NAO index. Geophys Res Lett 39: L21702. doi:10.1029/2012GL053413.

Wanner H, Bronnimann S, Casty C, Gyalistras D, Luterbacher J, Schmutz C, Stephenson DB, Xoplaki E (2001) North Atlantic Oscillation-concepts and studies. Surv Geophys 22: 321-382.

Wernli H, Dirren S, Liniger MA, Zillig M (2002) Dynamical aspects of the life-cycle of the winter storm "Lothar" (24-26 December 1999). Q J R Meteorol Soc 128: 405-429.

Woollings T, Hoskins B, Blackburn M, Berrisford P (2008) A New Rossby Wave-breaking Interpretation of the North Atlantic Oscillation. J Atmos Sci 65: 609-626.

Woollings T, Hannachi A, Hoskins B (2010) Variability of the North Atlantic eddy-driven jet stream. Q J R Meteorol Soc 136: 856-868. doi: 10.1002/qj.625

Woollings T, Gregory JM, Pinto JG, Reyers M, Brayshaw DJ (2012) Response of the North Atlantic storm track to climate change shaped by ocean-atmosphere coupling. Nature Geoscience 5:313-317.

Woollings T, Franzke C, Hodson DLR, Dong B, Barnes EA, Raible CC, Pinto JG (2015) Contrasting interannual and multi-decadal NAO variability. Clim Dyn 45:539-556. doi:10.1007/s00382-014-2237-y

Wunsch C (1999) The interpretation of short climate records, with comments on the North Atlantic and Southern Oscillations. Bull Amer Meteor Soc 80: 245-255

Zappa G, Masato G, Shaffrey L, Woollings T, Hodges K (2014) Linking Northern Hemisphere blocking and storm track biases in the CMIP5 climate models. Geophys Res Lett 41: 135-139. 
870 Table 1: Correlation coefficients between interannual cyclone track EOFs and climate indices in NCEP/ERA-

871 40/ECHAM5

\begin{tabular}{|c|c|c|c|c|c|c|}
\hline Corr. & $\mathbf{N A O}_{\mathrm{T}}$ & AO & PNA & Niño-34 & Jet1 ${ }_{\mathrm{T}}$ & Jet2 $_{\mathrm{T}}$ \\
\hline All1 $_{T}$ & $0.91 / 0.90 / 0.84$ & $0.78 / 0.79 / 0.56$ & $-0.23 /-0.23 /-\mathbf{0 . 1 7}$ & $-0.15 /-0.08 /-\mathbf{0 . 1 7}$ & $0.92 / 0.90 / 0.84$ & $-0.06 /-0.12 /-\mathbf{0 . 1 6}$ \\
\hline $\mathbf{E C 1}_{\mathrm{T}}$ & $0.78 / 0.88 / 0.66$ & $0.63 / 0.74 / 0.38$ & $-0.16 /-0.25 /-\mathbf{0 . 3 2}$ & $-0.11 /-0.27 /-\mathbf{0 . 1 3}$ & $0.72 / 0.85 / 0.59$ & $0.21 / 0.19 / \mathbf{0 . 2 9}$ \\
\hline $\mathbf{A l l 2}_{\mathrm{T}}$ & $0.08 / 0.10 / \mathbf{0 . 2 1}$ & $-0.14 /-0.18 / \mathbf{0 . 1 4}$ & $0.04 /-0.29 / \mathbf{0 . 1 7}$ & $0.04 / 0.14 / 0.04$ & $0.03 / 0.06 / \mathbf{0 . 1 5}$ & $0.55 / 0.55 / 0.36$ \\
\hline$\overline{E C 2} 2_{T}$ & $-0.12 /-0.04 /-\mathbf{0 . 3 6}$ & $-\mathbf{- 0 . 2 6} /-0.21 /-\mathbf{0 . 1 9}$ & $-0.05 / \mathbf{- 0 . 4 4} / 0.02$ & $0.04 / 0.20 / \mathbf{0 . 1 7}$ & $-0.22 /-0.21 /-\mathbf{0 . 5 3}$ & $0.65 / 0.78 / 0.50$ \\
\hline
\end{tabular}

872 Significant correlations $(95 \%$, $t$ test) are shown with bold face. Cells are shaded when the correlation is 873 significant for all datasets.

874

875 Table 2: Correlation coefficients between multi-decadal explosive cyclone track EOFs and low frequency ( $>11$ yr) climate indices in ECHAM5/MPIOM1.

\begin{tabular}{lccccccc}
\hline Corr. & NAO & PNA $_{L F}$ & AMO & IPO & AMOC & Jet1 LF & Jet2 LF \\
\hline EC1 $_{\text {LF }}$ & $\mathbf{0 . 7 5}$ & -0.08 & 0.24 & 0.16 & 0.11 & $\mathbf{0 . 6 8}$ & 0.15 \\
\hline EC2 $_{\text {LF }}$ & -0.25 & -0.01 & -0.12 & -0.09 & -0.04 & $\mathbf{- 0 . 4 2}$ & $\mathbf{0 . 6 0}$
\end{tabular}

Significant values $(95 \%, \mathrm{t}$ test $)$ are shown with bold face and shaded cells.

878 
881 Fig. 1: (a) Mean track density plots (in counts per $7.5^{\circ}$ radius circle area per DJF season) of explosive 882 (contours) and non-explosive (shadings) cyclones based on NCEP (base period 1948-2011; all cyclone time 883 steps included). (b) EOF1 and explained variance (\%) of DJF all cyclones (explosive + non-explosive) 884 anomalous track density fields (ALL1 1 ; shadings in track density units std $^{-1}-99 \%$ significance in stippling) and $885 \mathrm{u} 250\left(\mathrm{Jet} 1_{\mathrm{T}}\right.$; red/blue contours, starting from 2.5 in 0.5 intervals of $\left.\mathrm{m} \mathrm{s}^{-1} \mathrm{std}^{-1}\right)$ based on NCEP. The 886 climatological jet stream core is shown in thick black contours (starting from $30 \mathrm{~m} \mathrm{~s}^{-1}$ with $5 \mathrm{~m} \mathrm{~s}^{-1}$ intervals). (c)

887 Same as (b) but for explosive track density fields only. (d) 21-yr running correlations (centered) of EC1 $1_{\mathrm{T}}$ vs. $\mathrm{NAO}_{\mathrm{T}}$ (blue lines) and $\mathrm{EC} 1_{\mathrm{T}}$ vs. Jet1 $1_{\mathrm{T}}$ (red lines) for NCEP (solid lines) and ERA40 (dashed lines). All correlations are significant (95\% confidence interval, two sided $t$ test). The magenta line is the AMO index. 1948-1962 and 1963-1997 periods denoted with black dashed and black solid horizontal lines.

891

892

Fig. 2: (a) Same as Fig. 1(c) but for the re-calculated EOFs for the base period 1948-1962. (b) Same as (a) but for 1963-1997. (c) Regression (shadings, in $\mathrm{gpm} \mathrm{std}^{-1}$ ) and correlation (contours, $95 \%$ confidence interval) of z500 winter anomalies on $\mathrm{EC1}_{50 \mathrm{~s}}$ (period 1948-1962). (d) Same as (c) but for $\mathrm{EC}_{80 \mathrm{~s}}$ (base period 1963-1997). (e) Re-calculated NAO pattern ( $\mathrm{NAO}_{50 \mathrm{~s}}$; shadings in gpm std ${ }^{-1}$, contours every $10 \mathrm{gpm} \mathrm{std}^{-1}$ ) and explained variance (in \%) for the base period DJF 1948-1962. (f) Same as (e) but for 1963-1997 (NAO ${ }_{80 \mathrm{~s}}$ ). (g) Same as (c) but for SST winter anomalies on $\mathrm{EC}_{50 \text { s }}$ for the period 1948-1962 (in K std ${ }^{-1}$; based on HadISST). (h) Same as (g) but for $\mathrm{EC}_{80 \mathrm{~s}}$ (base period 1963-1997).

900

901

902

Fig. 3: (a) Climatological winter zonal wind at $250 \mathrm{hPa}$ (u250, contours in $\mathrm{m} \mathrm{s}^{-1}$ ) and 300-500 $\mathrm{hPa}$ maximum Eady Growth rate (bi400, shadings in day ${ }^{-1}$ ) on NCEP. (b) Difference of u250 intensity between 1948-1962 and 1963-1997 in red/blue shadings ( $\mathrm{m} \mathrm{s}^{-1} ; 95 \%$ confidence interval marked with + ). Difference of 300-500 hPa Eady Growth rate (bi400) in contours (day ${ }^{-1} ; 95 \%$ confidence interval marked with $x$ ). For the differences the means of the second period are subtracted to the first one. (c) Low frequency (>33-yr.) u250 anomalies averaged between $100^{\circ} \mathrm{W}-20^{\circ} \mathrm{W}$ in red/blue shadings $\left(\mathrm{m} \mathrm{s}^{-1}\right)$. The thick black line follows the latitudinal location of the maximum u250 positive anomalies. The thick dashed line is the decadal NAO index. Both indices are smoothed ( $>33$-yr low-pass filter), centered in the Y-axis and set to have the same standard deviation (the corresponding of 
the jet latitude index) to allow comparison. (d) Same as (b) but for the winter SST in red/blue shadings (in K, $95 \%$ confidence interval in contours).

Fig. 4: (a) Same as Fig. 1(a) but for ECHAM5 (base period DJF 1-505 model years). (b) Difference in mean of explosive track densities: ECHAM5 minus NCEP (shadings). Hatched areas depict significant differences (95\% confidence interval, $\mathrm{t}$ test for a difference in mean). (c) EOF1 and explained variance (\%) of low-frequency multi-decadal (>11-yr) DJF explosive anomalous track density fields $\left(E C 1_{\mathrm{LF}}\right.$; shadings - 99\% significance in stippling) and $\mathrm{u} 250$ (Jet1 $1_{\mathrm{LF}}$; red/blue contours, starting from 1 in $0.5 \mathrm{~m} \mathrm{~s}^{-1}$ std $^{-1}$ intervals) on ECHAM5 (base period DJF 1-505 years). (d) Same as Fig. 1(c) but for interannual timescales in ECHAM5 (1-11 yr.; $\mathrm{EC} 1_{\mathrm{T}} / \mathrm{Jet} 1_{\mathrm{T}}$ ). (e) Regression (shadings, in gpm std ${ }^{-1}$ ) and correlation (contours, $95 \%$ confidence interval) of $\mathrm{z} 500$ winter anomalies on interannual $\mathrm{EC}_{\mathrm{T}}(1-11 \mathrm{yr}$ ) for the total period of study on ECHAM5 (years 1-505). (f) Same as (e) but for winter SST anomalies $\left(\mathrm{K} \mathrm{std}^{-1}\right)$.

Fig. 5: (a) 21-yr running correlations (centered) of $E C 1_{T}$ vs. $N A O_{T} P C s$ (blue line) and $E C 1_{T}$ vs. Jet $1_{\mathrm{T}} P C s$ (red) on ECHAM5. Significant values highlighted with thicker red/blue segments $(95 \%$ confidence interval, two sided t test). 'Decoupling periods' denoted with vertical bars. (b) Magenta line: Spatial correlation of $\mathrm{NAO}_{\mathrm{T}}$ vs. the 485 running NAO patterns (based on 21-yr. sliding window EOFs). Blue line: Same as the magenta line but for the $485 \mathrm{EC} 1$ patterns vs. $\mathrm{EC1}_{\mathrm{T}}$. Red line: Latitudinal location (deg. N) of the main center of action of the 485 EC1 patterns (averaged over $90^{\circ} \mathrm{W}-40^{\circ} \mathrm{E}$ ). (c) Same as Fig. 2(e) but for the decoupling periods on ECHAM5 (model years 182-209 and 305-327). (d) Same as Fig. 2(a) but for the decoupling periods on ECHAM5. (e) Same as Fig. 2(c) but for the decoupling periods on ECHAM5. (f) Same as Fig. 2(g) but for the decoupling periods on ECHAM5/MPIOM1.

Fig. 6: (a) Explosive track density anomaly for the decoupling periods (shadings; 95\% confidence interval hatched) and standard deviation anomaly (contours; standard units, 95\% confidence interval - filled dots). (b) Climatological winter zonal wind at $250 \mathrm{hPa}\left(\mathrm{u} 250\right.$, contours in $\left.\mathrm{m} \mathrm{s}^{-1}\right)$ and 300-500 hPa maximum Eady Growth rate (bi400, shadings in day $^{-1}$ ) on ECHAM5. (c) Winter $\mathrm{u} 250$ anomaly (red/blue shadings in $\mathrm{m} \mathrm{s}^{-1}, 95 \%$ confidence interval marked with + ) and 300-500 hPa Eady Growth rate anomaly (bi400, contours in day ${ }^{-1}, 95 \%$ confidence interval marked with $x$ ) during the decoupling periods. (d) Same as Fig. 3(c) but for ECHAM5. Decoupling periods marked with vertical bars. 
940 Fig. 7: (a) Mean oceanic heat content (OHC) from 0 to $123 \mathrm{~m}$ (thermocline depth over the sub-tropical North 941 Atlantic) in MPIOM1 (shadings in $10^{9} \mathrm{~J} \mathrm{~m}^{-2}$ ) and its meridional gradient (סyOHC) (contours in $10^{9} \mathrm{~J} \mathrm{~m}^{-2} * 10^{-3}$ $942 \mathrm{~km})$. (b) Winter SST anomalies in shadings (K) and significant areas (95\% confidence interval) in contours 943 during the decoupling periods. Winter $\mathrm{OHC}$ significant anomalies $\left(10^{9} \mathrm{~J} \mathrm{~m}^{-2}\right)$ in stippling. (c) Meridional $\mathrm{OHC}$ 944 gradient anomaly $\left(\delta_{\mathrm{y}} \mathrm{OHC}\right)$ (shadings in $10^{9} \mathrm{~J} \mathrm{~m}^{-2} * 10^{-3} \mathrm{~km}$ ) during the decoupling periods. Significant areas 945 (95\% confidence interval) in stippling. (d) Low pass filtered water temperature anomalies ( $>33$ yr.; in SU) 946 averaged over the area $\left(30^{\circ}-40^{\circ} \mathrm{N}, 60^{\circ}-30^{\circ} \mathrm{W}\right.$, dashed rectangle in Fig. $\left.7 \mathrm{~b}\right)$ at different ocean depth levels $(0,6$, 94769 and 123 meters - see legend). Low pass filtered AMOC index ( $>33$ yr.; dashed black curve in SU).

949 Fig. 8: (a) Schematic of the leading variability mode (1-11 yr.) of explosive cyclone tracks under normal conditions in ECHAM5/MPIOM1. EOF1 EC $\left(\mathrm{EC}_{\mathrm{T}}\right)$ in red shadings. Leading EOFs of u250 (1-11 yr.) in contours. These are the three preferred positions of the interannual jet (Woollings et al. 2010): (1) red Jet1 $1_{\mathrm{T}}+\mathrm{NAO}+;$ (2) blue - Jet1 $1_{\mathrm{T}} / \mathrm{NAO}$; and (3) black - Jet $2_{\mathrm{T}}+$. Main genesis area of explosive North Atlantic cyclones in stippling (values above 0.5 counts per $7.5^{\circ}$ radius circle area per DJF). (b) Same as (a) but for the decoupling periods.

955

Fig. 9: (a) Composite of DJF bi400 (shadings in day $^{-1}$ ) under $\mathrm{NAO}_{\mathrm{T}}^{+}(>1 \mathrm{SU} ; 88$ members). Base period: 1-505

957 yr. The areas of values above 40 day $^{-1}$ are highlighted in stippling. (b) Same as (a) but under $\mathrm{NAO}_{\mathrm{T}^{-}}(<-1 \mathrm{SU} ; 88$ members). (c) Same as (a) but under $\mathrm{NAO}_{\mathrm{D}}+(>1 \mathrm{SU} ; 8$ members) during the decoupling periods. (d) Same as (a) but under $\mathrm{NAO}_{\mathrm{D}^{-}}(<-1 \mathrm{SU} ; 8$ members $)$ during the decoupling periods.

961 Fig. 10: Quantification of bi400 extent/strength over the North Atlantic: sum of all values in stippling from Figs.

962 9a-d associated with the extratropical jet (sub-tropical jet areas removed). The final values are normalized (in \%) with respect to the climatological $\mathrm{NAO}_{\mathrm{T}}+$ absolute value (Fig. 9a). 


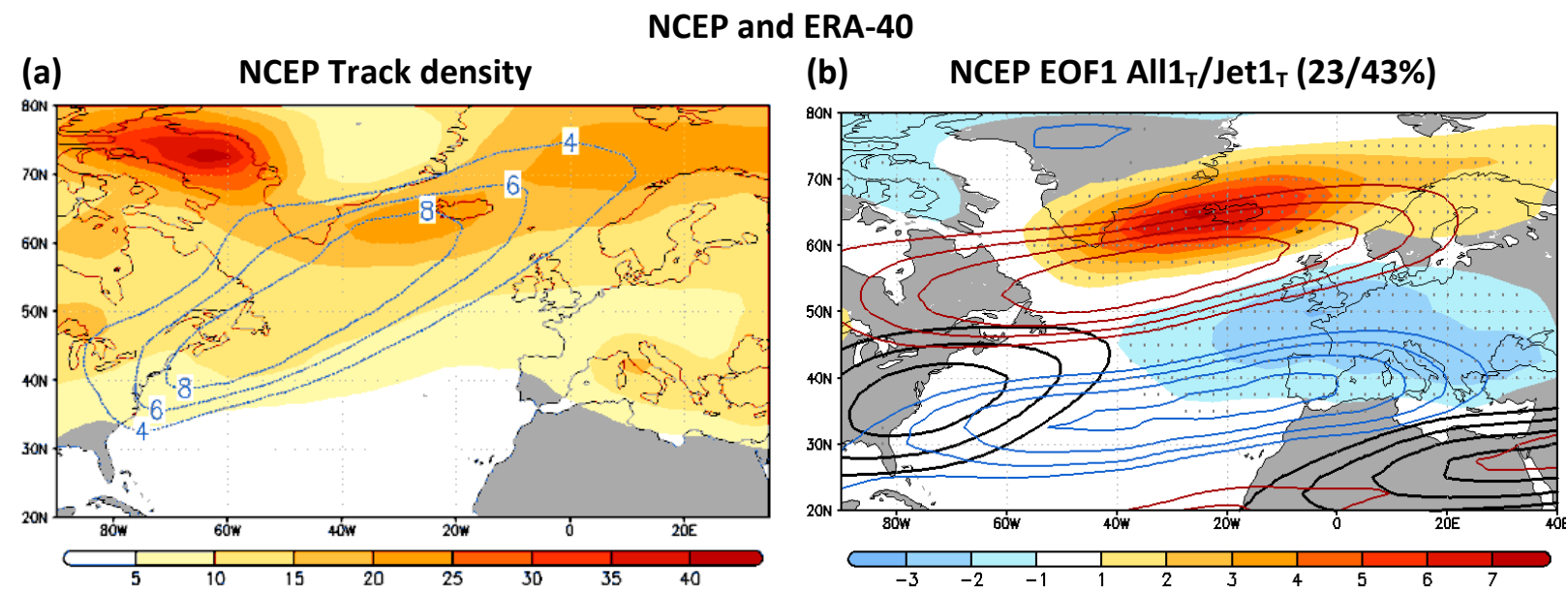

(c) NCEP EOF1 EC1 $1_{\mathrm{T}} / \operatorname{Jet}_{\mathrm{T}}(32 / 43 \%)$

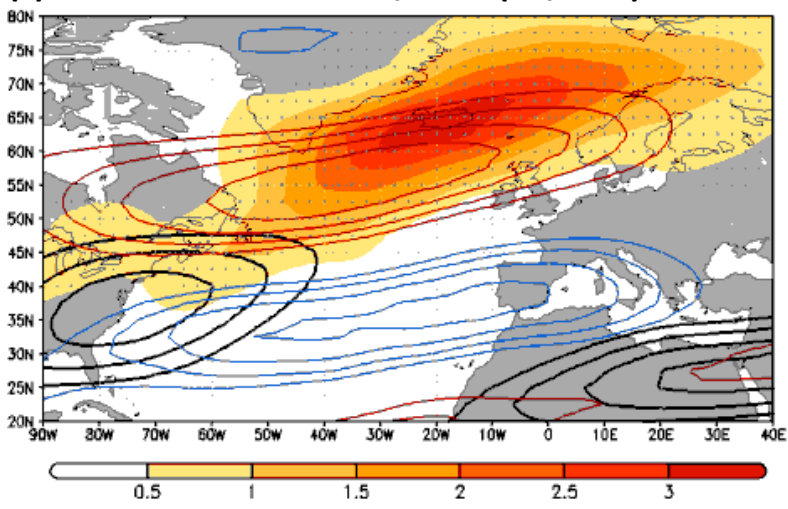

(d) Running correlations: $\mathrm{EC1}_{\mathrm{T}} \mathrm{Vs}$. $\mathrm{NAO} \mathrm{O}_{\mathrm{T}} /$ Jet $_{\mathrm{T}}$

964 Fig. 1

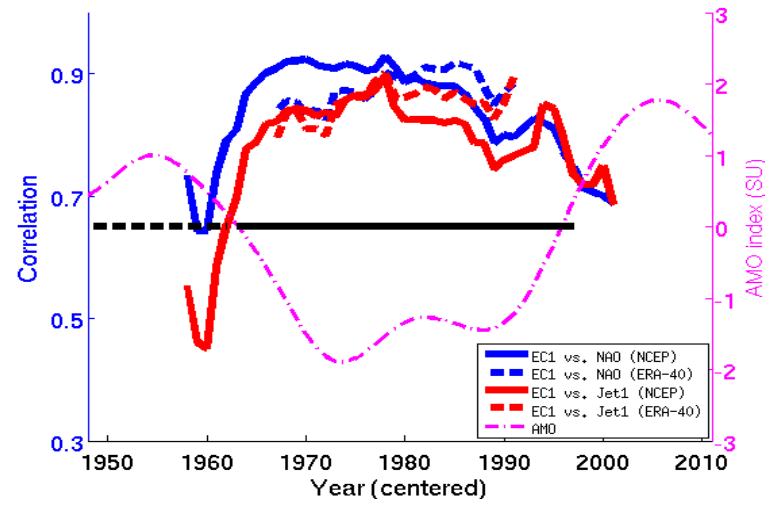


(a) EOF1 EC1 $1_{50 s} /{ }^{J e t} 1_{50 s}(36 / 32 \%)$ 1948-1962

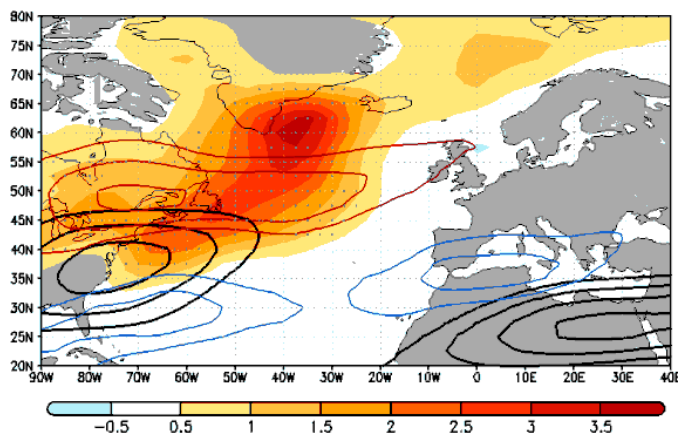

(c) Regression: $\mathbf{z 5 0 0}-\mathrm{EC1}_{50 \mathrm{~s}}$

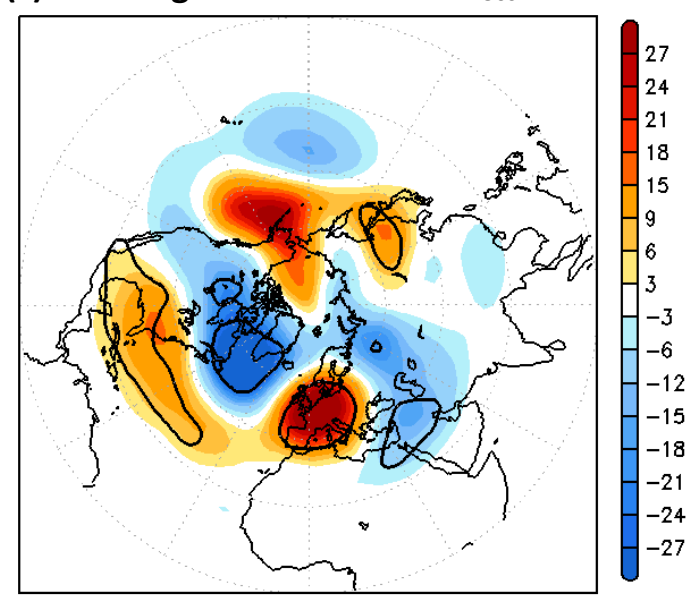

(e)

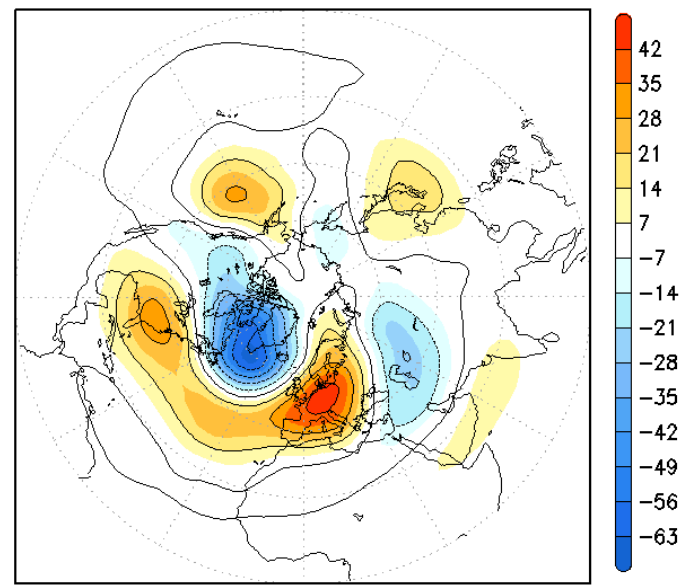

(g) Regression: SST - EC1 50 s

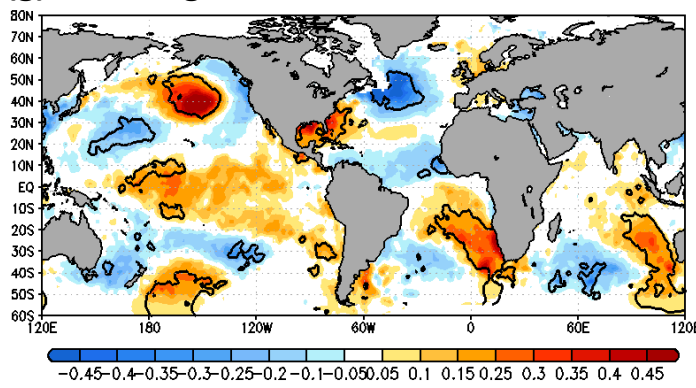

Fig. 2
NCEP

(b) EOF1 EC1 $1_{80 \mathrm{~s}} / \mathrm{Jet}_{80 \mathrm{~s}}(40 / 56 \%)$ 1963-1997

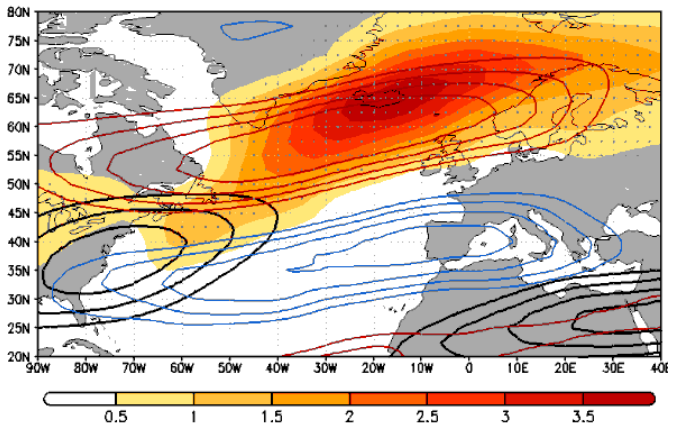

(d) Regression: $\mathbf{z 5 0 0}-\mathrm{EC1}_{80 \mathrm{~s}}$

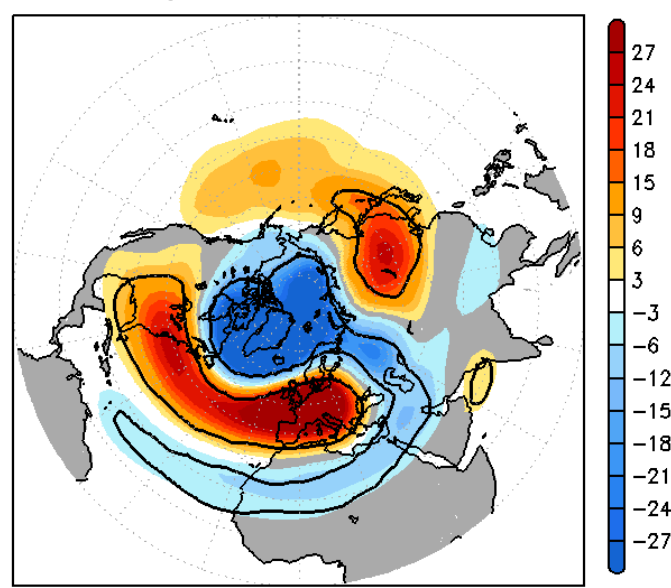

(f)

$\mathrm{NAO}_{80 \mathrm{~s}}(52 \%)$

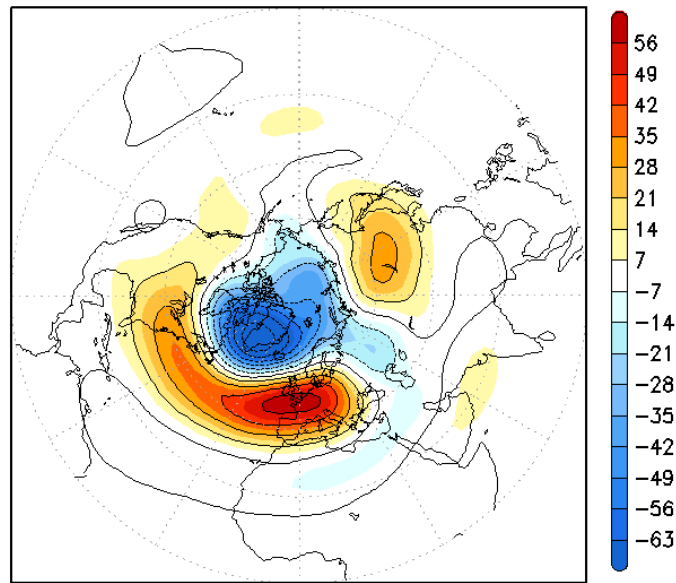

(h) Regression: SST - EC1 ${ }_{80 \text { s }}$

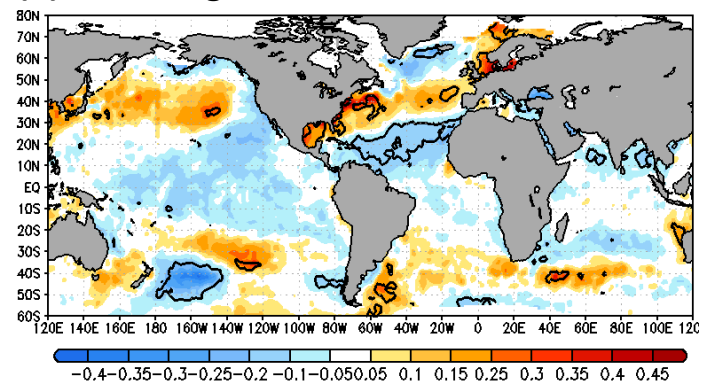


(a)

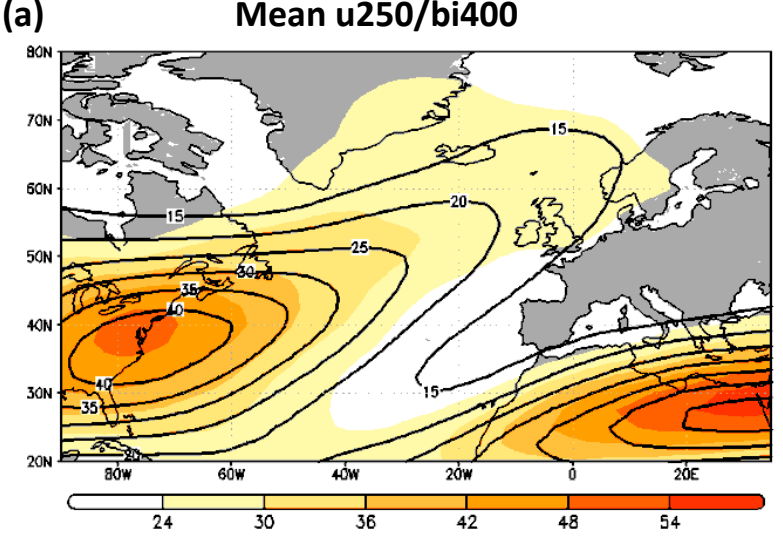

(c) Decadal jet/NAO variability

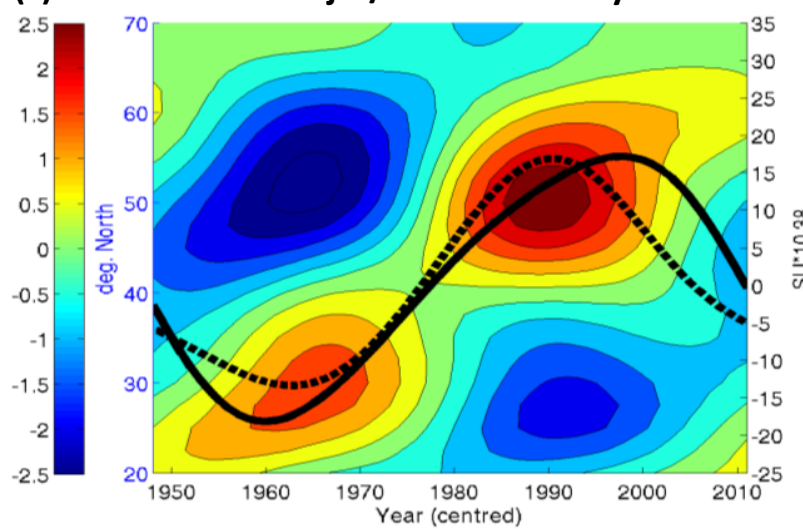

968 Fig. 3
NCEP

(b) Difference u250/bi400 50s-80s

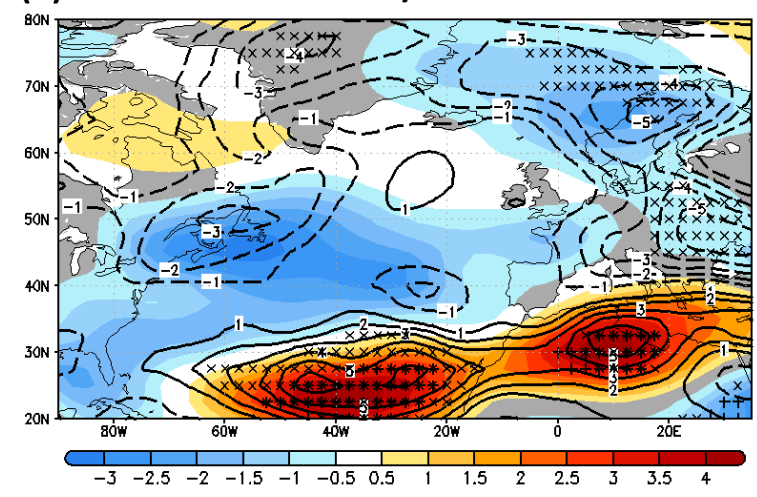

(d) Difference SST 50s-80s

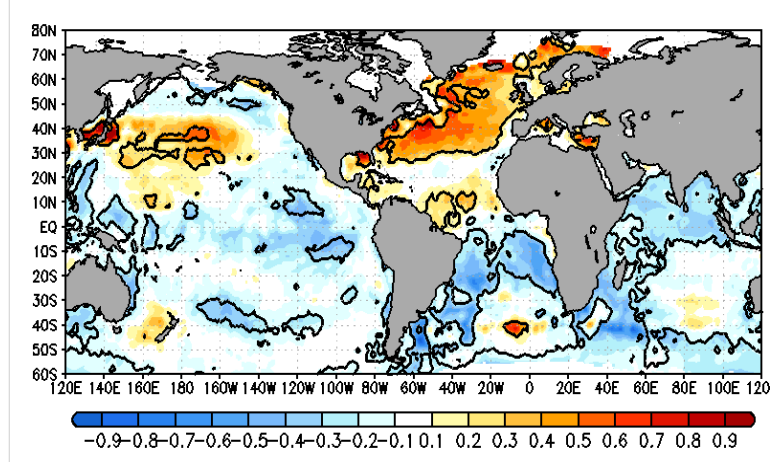



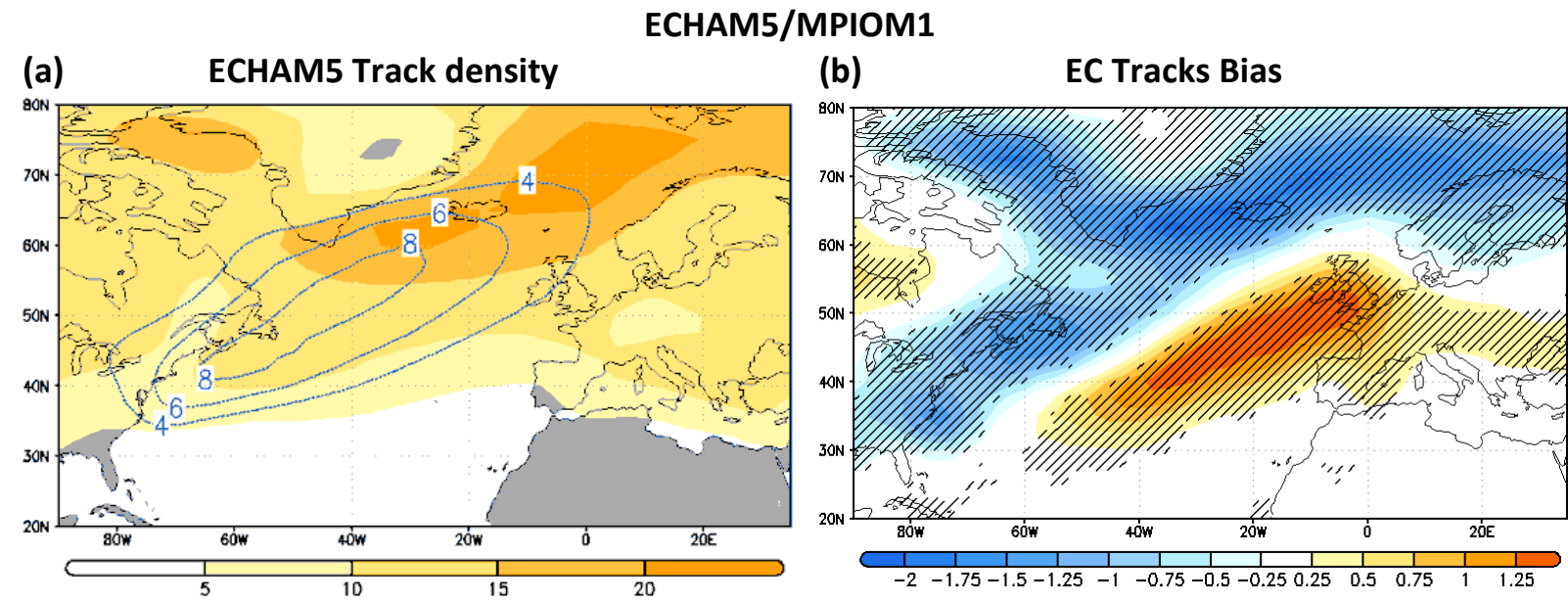

(c) EOF1 (>11-yr) EC1 $1_{\mathrm{LF}} /$ Jet $_{\mathrm{LF}}(31 / 34 \%)$

(d) $\operatorname{EOF1}(1-11 \mathrm{yr}) \mathrm{EC1}_{\mathrm{T}} / \operatorname{Jet} 1_{\mathrm{T}}$ (27/31\%)
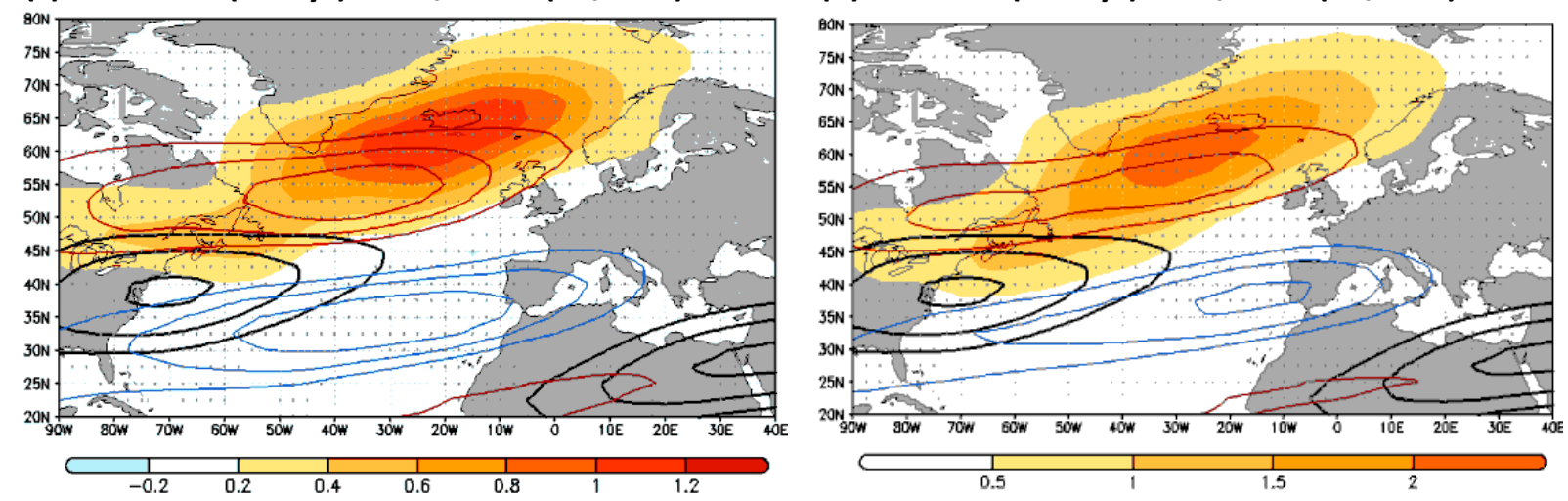

(e) Regression: 2500 - EC1 $(1-11 \mathrm{yr})$

(f) Regression: SST - EC1 ${ }_{\mathrm{T}}(1-11 \mathrm{yr})$
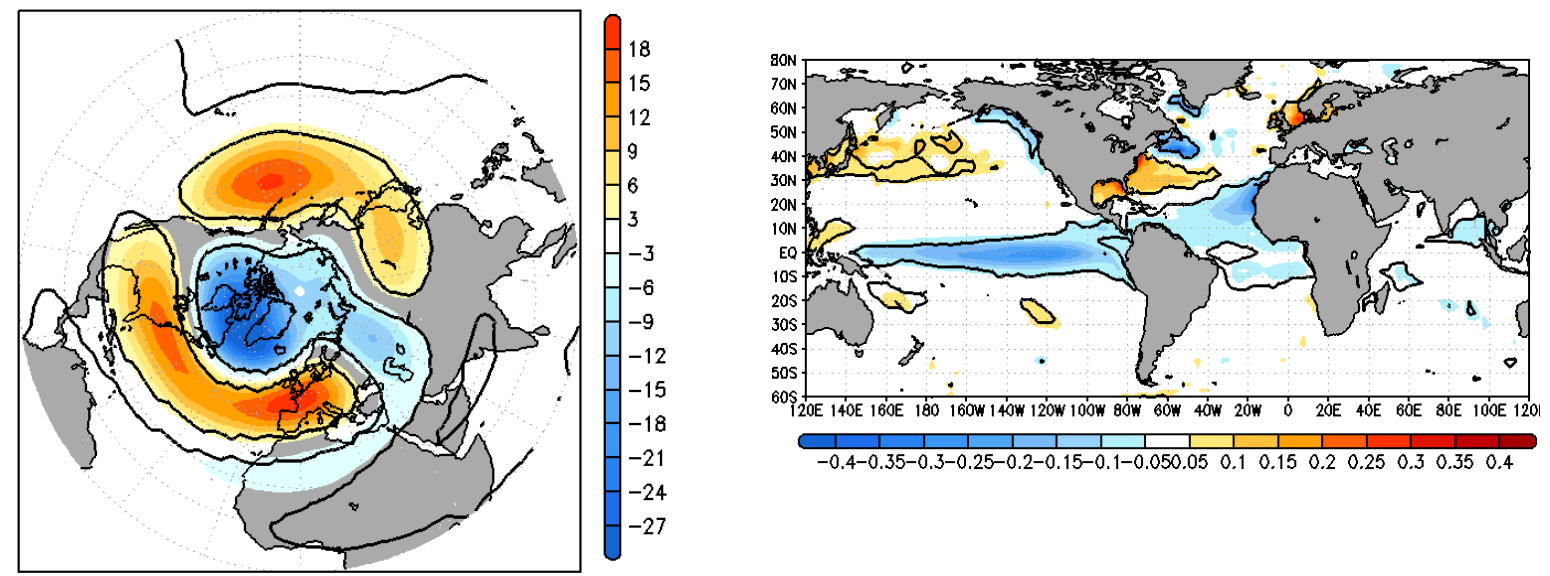

$972 \quad$ Fig. 4

973 
ECHAM5/MPIOM1

(a) Running correlations: $\mathrm{EC1}_{\mathrm{T}} \mathrm{vs}$. $\mathrm{NAO} \mathrm{T}_{\mathrm{T}} / \mathrm{Jet}_{\mathrm{T}}$

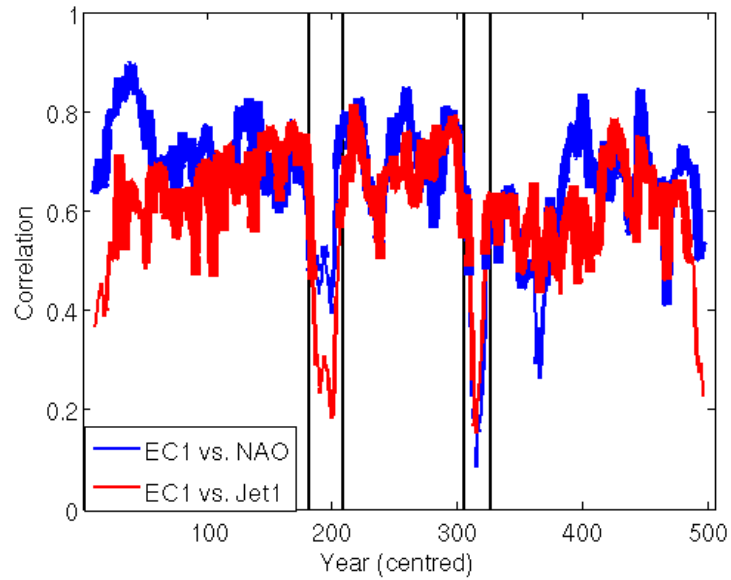

(c)

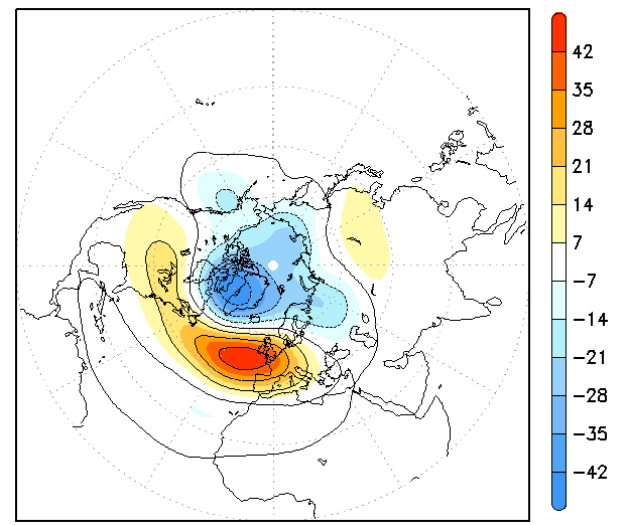

(e)

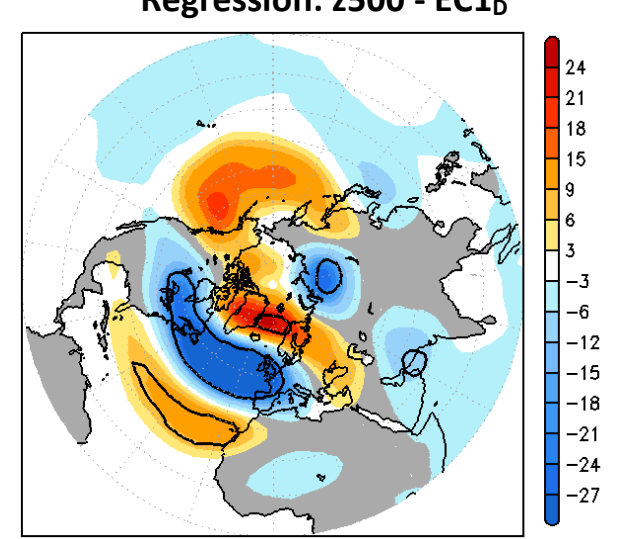

(b) Changes in the EOF patterns

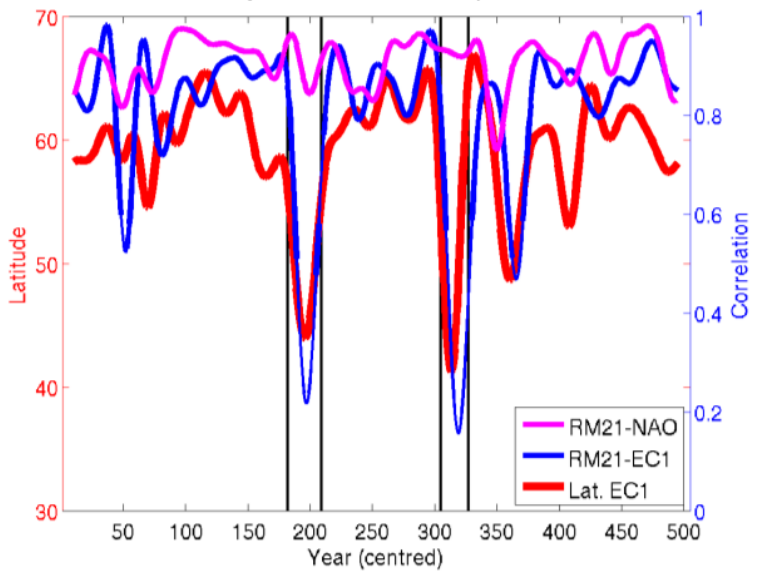

(d) $E C 1_{D} /$ Jet $_{D}$ (26/36\%): decoupling periods
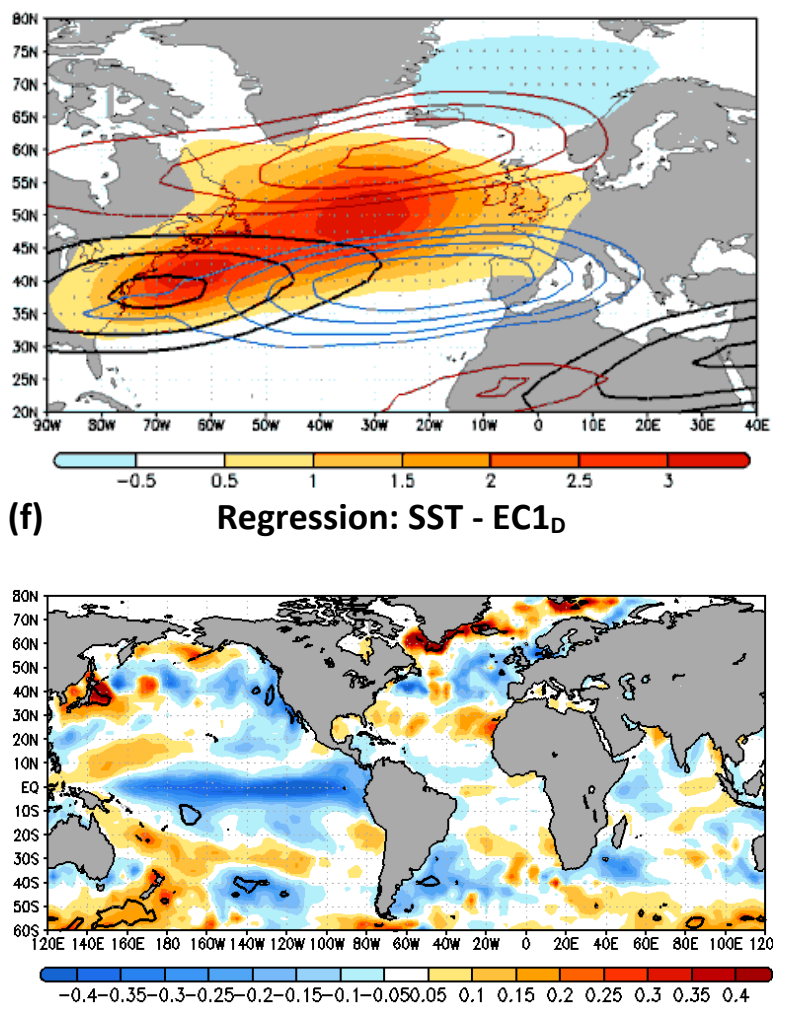
ECHAM5/MPIOM1: DECOUPLING PERIODS - ATMOSPHERE

(a) Track-densities: mean/variance anomaly

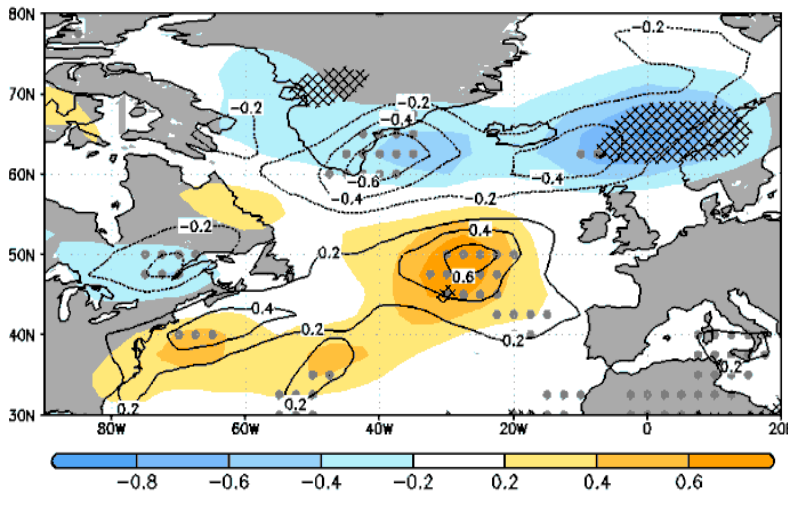

(c)

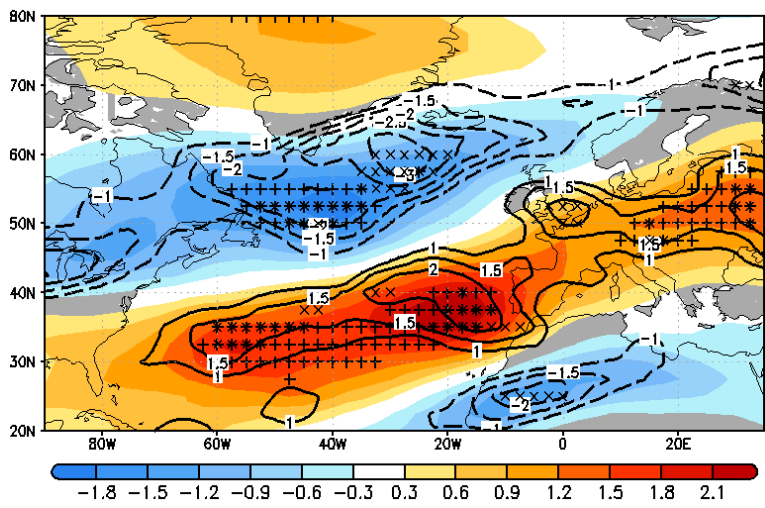

(b)

Mean u250/bi400

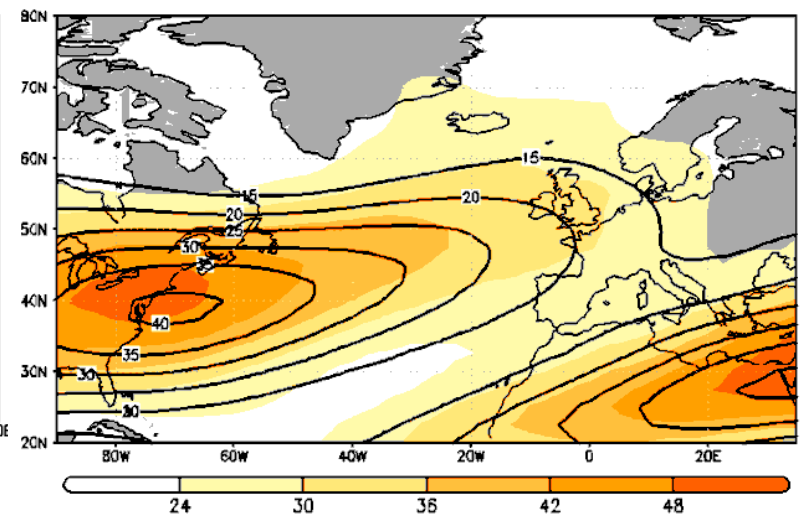

(d) Decadal jet/NAO variability (>33 yr.)

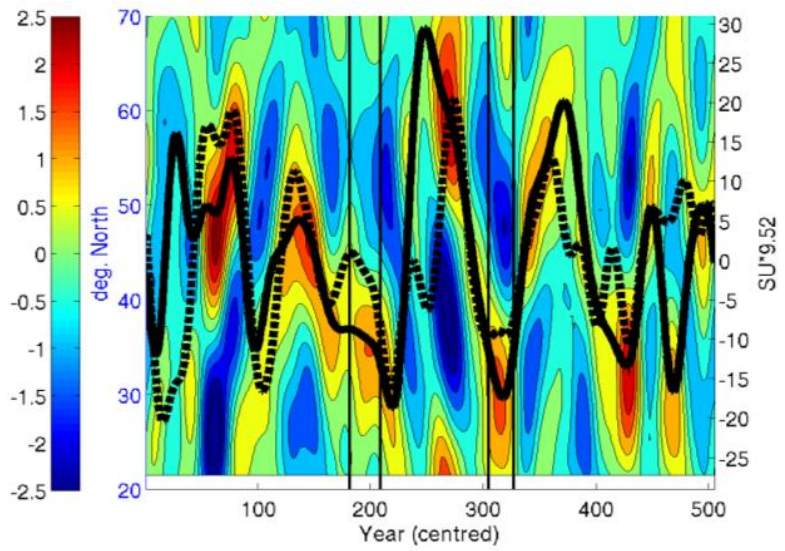

Fig. 6 


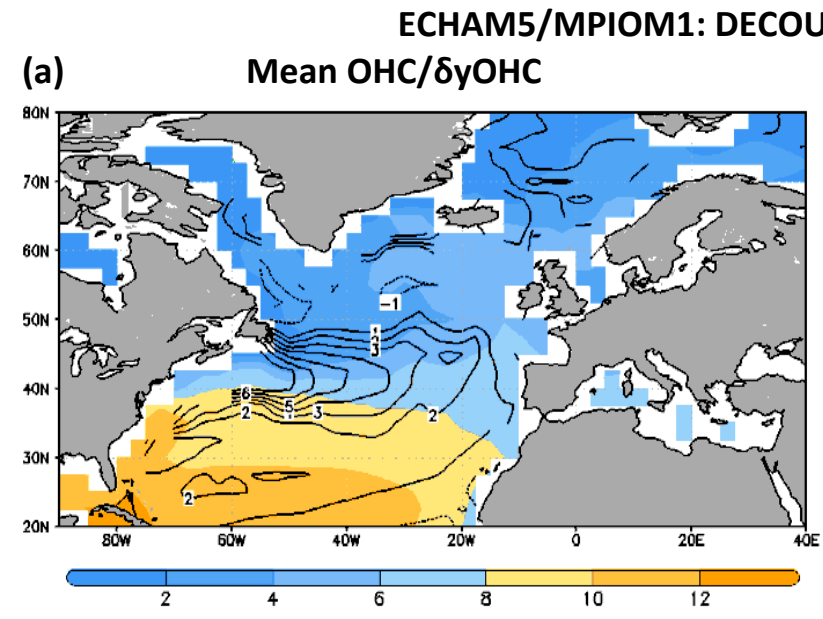

(c)

(b) Anomaly SST/OHC

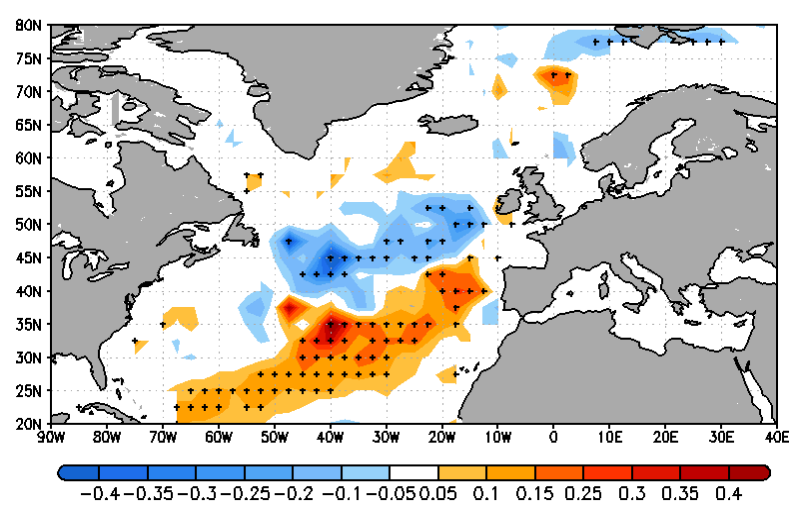

(d) SST/T/AMOC anomaly indices

$979 \quad$ Fig. 7
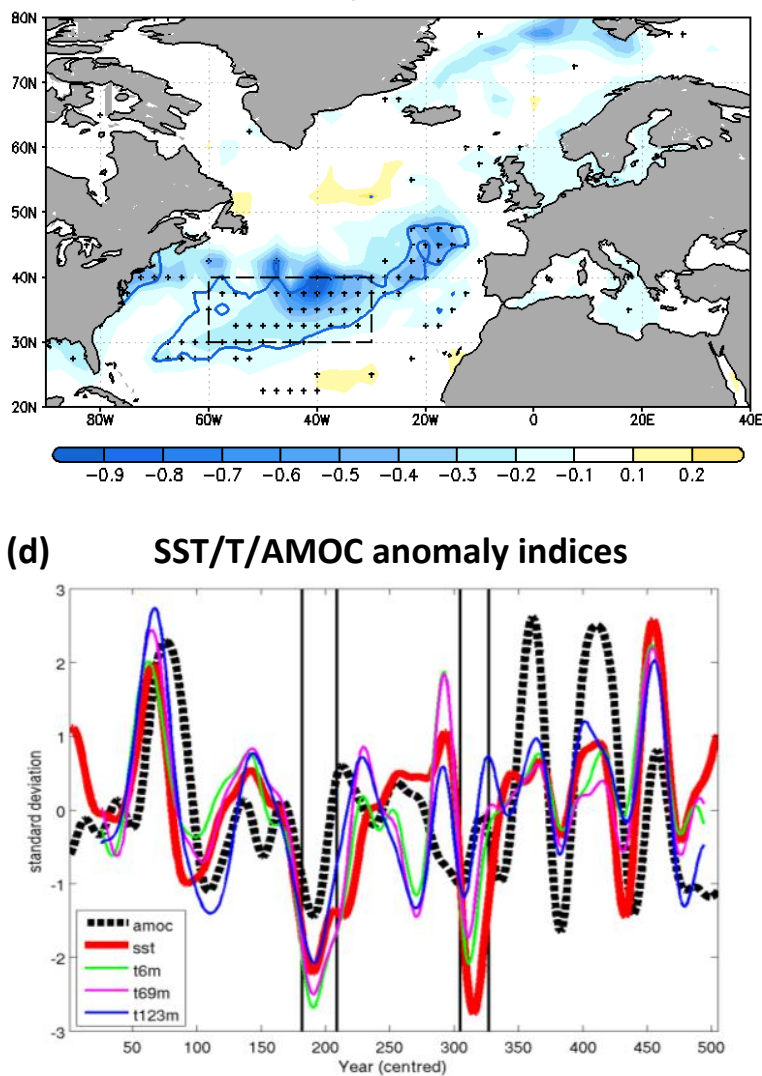

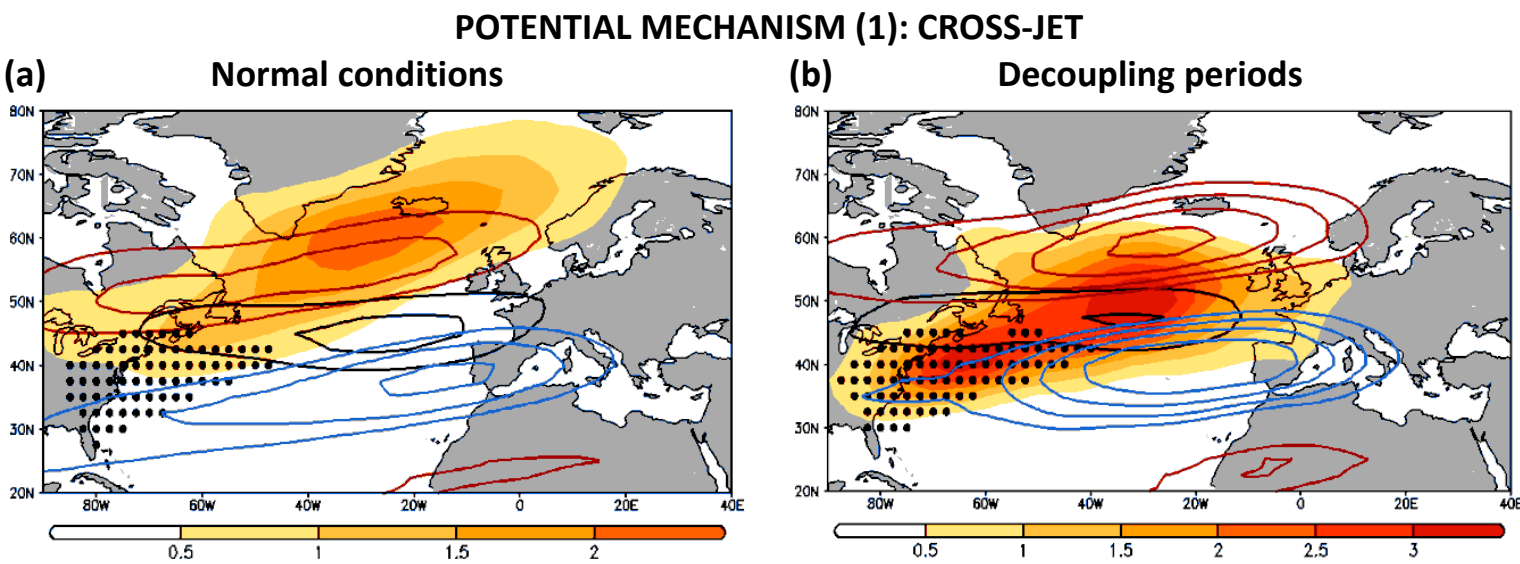

$980 \quad$ Fig. 8

981 


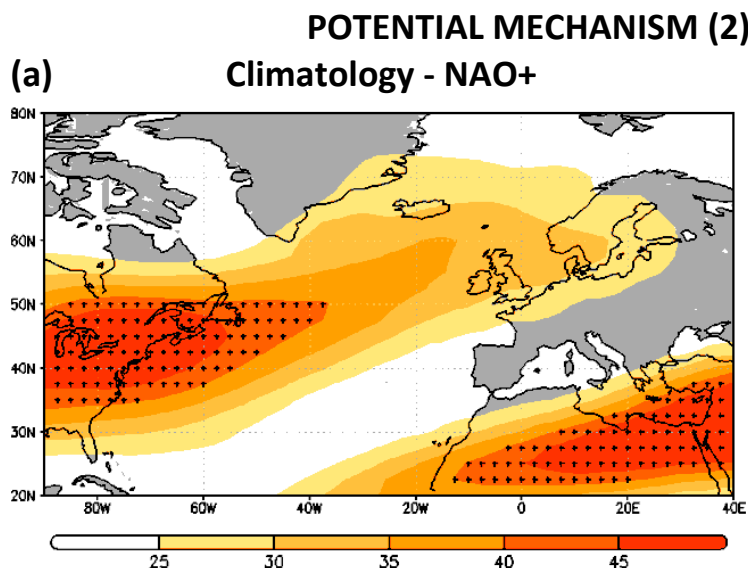

NAO PHASE - BAROCLINICITY

(c)

(b) Climatology - NAO-
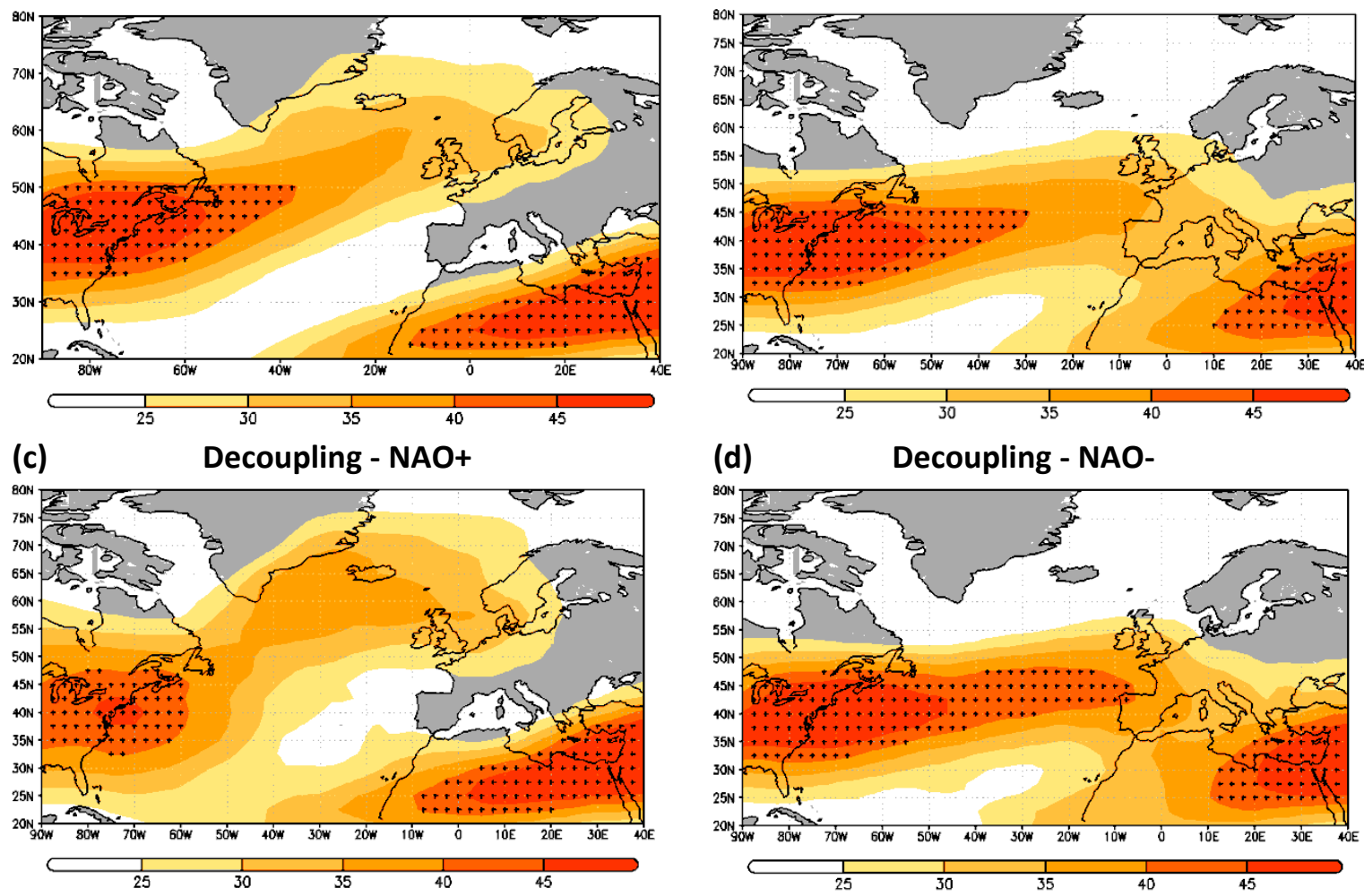

(d)

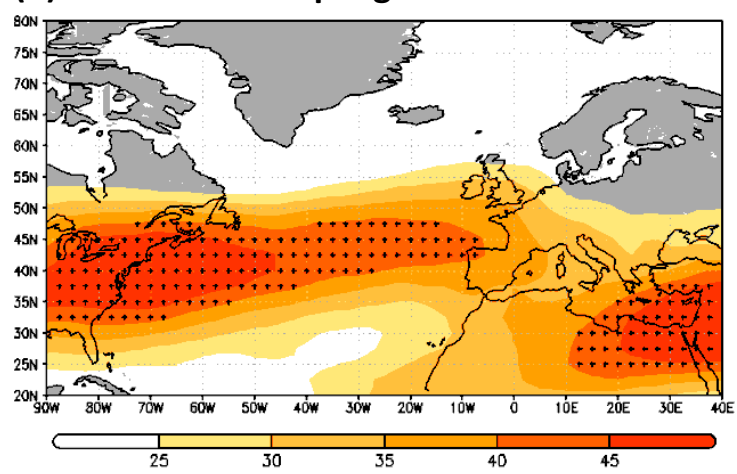

$982 \quad$ Fig. 9 
NAO phase vs. Baroclinicity extent/strength

985

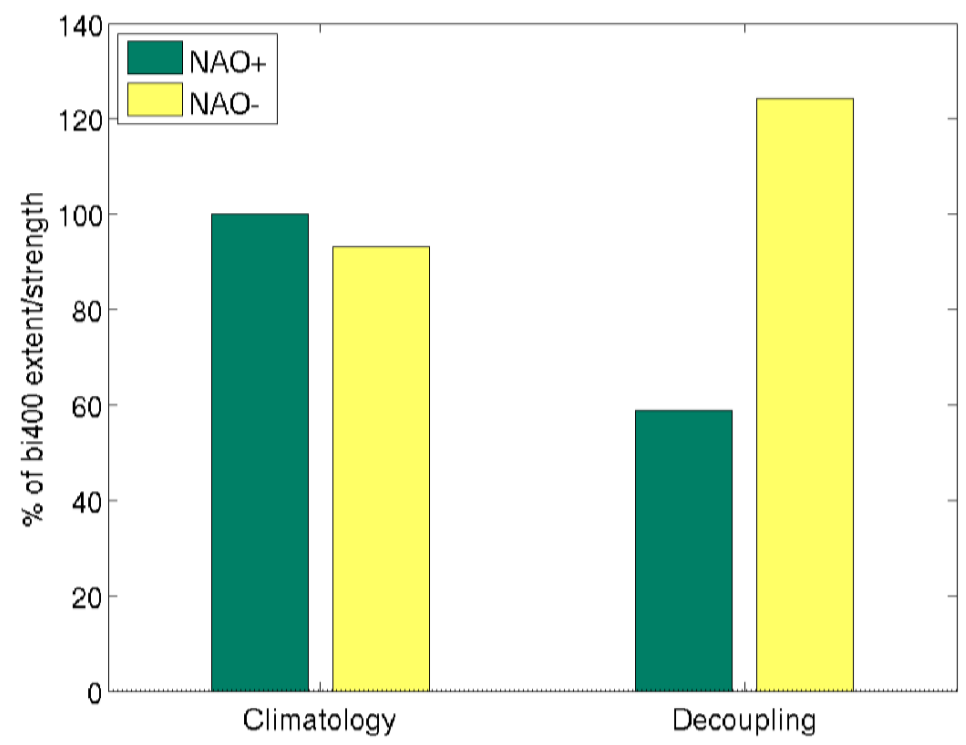

986 Fig. 10 